\title{
Intraspecific variability in the early Miocene struthiolariid gastropod Perissodonta ameghinoi (Ihering, 1897) from Tierra del Fuego, Argentina
}

MARIA I. LÓPEZ CABRERA ${ }^{1}$

EDUARDO B. OLIVERO ${ }^{1,2}$

1. Consejo Nacional de Investigaciones Científicas y Técnicas (CONICET), Centro Austral de Investigaciones Científicas (CADIC-CONICET). B. A. Houssay 200, 9410 Ushuaia, Tierra del Fuego, Argentina.

2. Universidad Nacional de Tierra del Fuego, Instituto de Ciencias Polares y Ambientales (UNTDF-ICPA). Walanika 250, 9410 Ushuaia, Tierra del Fuego, Argentina.

Recibido: 1 de marzo 2021 - Aceptado: 24 de julio 2021 - Publicado: 22 de septiembre 2021

Para citar este artículo: Maria I. López Cabrera and Eduardo B. Olivero (2021). Intraspecific variability in the early Miocene struthiolariid gastropod Perissodonta ameghinoi (Ihering, 1897) from Tierra del Fuego, Argentina. Publicación Electrónica de la Asociación Paleontológica Argentina 21(2), 34-52.

Link a este artículo: http://dx.doi.org/10.5710/PEAPA.24.07.2021.388

๑2021 López Cabrera and Olivero

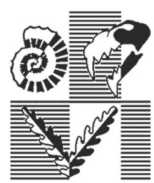

ISSN 2469-0228
Asociación Paleontológica Argentina

Maipú $6451^{\circ}$ piso, C1006ACG, Buenos Aires

República Argentina

Tel/Fax (54-11) 4326-7563

Web: www.apaleontologica.org.ar
Acceso Abierto Open Access

This work is licensed under CC BY-NC 4.0

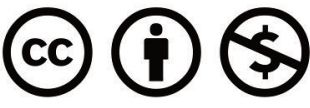




\title{
INTRASPECIFIC VARIABILITY IN THE EARLY MIOCENE STRUTHIOLARIID GASTROPOD PERISSODONTA AMEGHINOI (IHERING, 1897) FROM TIERRA DEL FUEGO, ARGENTINA
}

\author{
MARÍA I. LÓPEZ CABRERA ${ }^{1}$ AND EDUARDO B. OLIVERO ${ }^{1,2}$ \\ ${ }^{1}$ Consejo Nacional de Investigaciones Científicas y Técnicas (CONICET), Centro Austral de Investigaciones Científicas (CADIC-CONICET). B. A. Houssay 200, 9410 Ushuaia, \\ Tierra del Fuego, Argentina.emolivero@gmail.com \\ ${ }^{2}$ Universidad Nacional de Tierra del Fuego, Instituto de Ciencias Polares y Ambientales (UNTDF-ICPA). Walanika 250, 9410 Ushuaia, Tierra del Fuego, Argentina.
}

EBO: https://orcid.org/0000-0001-5704-6294

\begin{abstract}
The early Miocene marine deposits in Tierra del Fuego bear a group of struthiolariid gastropods that stand out for their high morphological variability. Since the end of the $19^{\text {th }}$ century this variability was interpreted as reflecting (1) a highly diversified rapidly evolving group of species or (2) a single, plastic species characterized by ample intraspecific variability. The morphological study of more than 100 specimens of the Fuegian struthiolariid genus Perissodonta Martens collected in the Carmen Silva, Viamonte, and Irigoyen formations indicate that significant parameters, such as shell shape, spire length and number of spiral and axial sculptures (cords, threads, tubercles) vary continuously within an ample range of values, favoring a single, plastic species. Topotype specimens of Perissodonta ameghinoi (Ihering), collected from the early Miocene Monte León Formation in Patagonia, show similar plasticity of characters. Furthermore, recent topotype material of Perissodonta georgiana Strebel from Islas Georgias del Sur, a species considered very close or junior synonym of the genotype species $P$. mirabilis (Smith), indicates a similar degree of plasticity. Accordingly, the Fuegian struthiolariids previously assigned to Perissodonta ameghinoi; P. fueguina (Ihering); or P. densestriata (Ihering) are here referred to P. ameghinoi, a struthiolariid gastropod restricted to the early Miocene in Tierra del Fuego and Patagonia.
\end{abstract}

Key words. Struthiolariid. Perissodonta ameghinoi. Intraspecific variability. Miocene. Tierra del Fuego. Argentina.

Resumen. VARIABILIDAD INTRAESPECÍFICA DEL GASTRÓPODO STRUTHIOLARIDO PERISSODONTA AMEGHINOI (IHERING, 1897), MIOCENO TEMPRANO, TIERRA DEL FUEGO, ARGENTINA. Los depósitos marinos del Mioceno temprano en Tierra del Fuego albergan un grupo de gasterópodos struthiolaridos que se destacan por su alta variabilidad morfológica. Desde finales del siglo 19 se interpretó que esta variabilidad reflejaba (1) un grupo de especies altamente diversificado en rápida evolución o (2) una única especie plástica caracterizada por una amplia variabilidad intraespecífica. El estudio morfológico de más de 100 ejemplares del género Perissodonta Martens recolectados en las formaciones fueguinas Carmen Silva, Viamonte e Irigoyen indica que parámetros significativos, como la forma del caparazón, la longitud de la espira y el número de ornamentaciones espirales y axiales (líneas espirales finas, cordones, tubérculos) varían continuamente dentro de una amplia gama de valores, favoreciendo una única especie plástica. Los especímenes topotipo de Perissodonta ameghinoi (Ihering), recolectados de la Formación Monte León del Mioceno temprano en la Patagonia, muestran una plasticidad de caracteres similar. Además, material de topotipo reciente de Perissodonta georgiana Strebel de las Islas Georgias del Sur, una especie considerada sinónimo muy cercano o junior del genotipo de la especie $P$. mirabilis (Smith), indica un grado similar de plasticidad. En consecuencia, los struthiolaridos fueguinos asignados previamente a Perissodonta ameghinoi; P. fueguina (Ihering) o P. densestriata (Ihering) se refieren en este trabajo a P. ameghinoi, un gasterópodo struthiolarido restringido al Mioceno temprano en Tierra del Fuego y Patagonia.

Palabras clave. Struthiolaridos. Perissodonta ameghinoi. Variabilidad intraespecífica. Mioceno. Tierra del Fuego. Argentina.

MIOCENE MARINE DEPOSITS of Tierra del Fuego bear a group of struthiolariid gastropods that stand out for their high morphological variability, particularly regarding their spiral and axial sculptures, i.e., number and strength of spiral cords, threads, and tubercles. In the struthiolariid material originally described from the South Atlantic coast of Santa Cruz and Tierra del Fuego, this variability was interpreted as reflecting either (1) a number of different species typifying a highly diversified and rapidly evolving group (e.g., Ihering, 1897, 1907; Ortmann, 1902; Camacho \& Zinsmeister, 1989) or (2) a single, plastic species characterized by ample intraspecific variability (e.g., Steinmann \& Wilckens, 1908). Both interpretations, however, were generally based on scarce material and limited stratigraphic data, hampering 
proper evaluation on the validity of these contrasting views.

The struthiolariid gastropods collected from early Miocene deposits along the Atlantic coast of Santa Cruz and Tierra del Fuego have been generally split into a number of species or varieties, totalizing a number of seven species of Perissodonta Martens, 1878, which include P. ornata (Sowerby, 1846), P. ameghinoi (lhering, 1897), P. multinodosa (Ortmann, 1902), P. fueguina (Ihering, 1907), P. densestriata (Ihering, 1907), P. cuevensis (Camacho \& Zinsmeister, 1989), and P. patagoniensis (Camacho \& Zinsmeister, 1989) (see also Genta Iturrería \& Griffin, 2018). In the Atlantic coast of Santa Cruz the first known struthiolariid from Patagonia is Perissodonta ornata that was described by Sowerby while studying the material collected by Darwin (1846) from marine deposits of the Monte León Formation, Santa Cruzsee Griffin \& Nielsen (2008) and Parras \& Griffin (2009) for a detailed stratigraphic account of Darwin's localities and Nielsen (2005) and López Cabrera \& Olivero (2018) regarding the generic assignation. Subsequently, Ihering (1897, 1907) studied struthiolariid gastropods from the Monte León (early Miocene) and the San Julián (latest Oligoceneearliest Miocene) formations. Additional struthiolariid species-and varieties subsequently elevated to specific rank - were studied by Ortmann (1902) and Camacho \& Zinsmeister (1989). Struthiolariid gastropods from the Monte León Formation were also mentioned and figured by del Río (2002, 2004). Earliest mentions of fossil Perissodonta from the Miocene of Tierra del Fuego are from the Carmen Silva Formation (Ihering, 1907; Steinmann \& Wilckens, 1908). Additional material from this formation was described by Malumián et al. (1978), Camacho \& Zinsmeister (1989), López Cabrera \& Olivero (2018), and mentioned by Feldmann et al. (2011).

Perissodonta is abundant in the early Miocene deposits of Tierra del Fuego and more than 100 specimens have been collected by the authors from five localities, i.e., Sierra Carmen Silva, Punta Basílica, Cerro Águila, Cabo Viamonte, and Río Irigoyen (Fig. 1). Specimens of Perissodonta in our collection are characterized by highly variable morphological characters, particularly regarding the shell shape, type and character of the inductura, suture and siphonal canal, and strength and number of spiral cords, spiral threads and tubercles. As mentioned above, this variability has been interpreted as typifying rapidly evolving different species or intraspecific variation within a single species. Therefore, the purpose of this paper is to review the taxonomy of the Perissodonta species from Tierra del Fuego. To accomplish this task, we characterize the morphological variability of a large collection of Fuegian specimens collected from different, but basically coeval stratigraphic units, and the resulting pattern is used to evaluate the paleobiological significance of the variability. Based on these studies, the main conclusion is that most likely the studied material corresponds to a single, highly variable species, which can be accommodated in Perissodonta ameghinoi, as Steinmann \& Wilckens (1908) and López Cabrera \& Olivero (2018) have suggested before.

\section{GEOLOGICAL SETTING}

The Upper Cretaceous-Cenozoic sedimentary deposits of Tierra del Fuego integrate the Austral (Magallanes) and part of the Malvinas foreland basins. In central and northern Tierra del Fuego the Río Chico Arch, a structural high of basement rocks, separates the Austral basin from the Malvinas basin. To the south, this structural high disappears and both basins are integrated (Fig. 1; Biddle et al., 1986; Galeazzi, 1998; Olivero et al., 2002; Torres Carbonell \& Olivero, 2019). The Austral and Malvinas foreland basins share a geologically similar sedimentary fill, which accumulated synchronously with several contractional stages following a major ductile deformation phase, associated with the closure and inversion of the predecessor Late JurassicEarly Cretaceous Rocas Verdes back-arc basin (Dalziel, 1981; Torres Carbonell et al., 2020, and the bibliography therein). Within the thrust and fold belt, the Late Cretaceous to Oligocene-earliest Miocene foreland basin fill consists of three unconformity-bounded syntectonic clastic wedges of Late Cretaceous-Danian, Paleocene-early mid Eocene, and late mid Eocene-Oligocene-earliest Miocene age. These clastic wedges accumulated in successive elongated foredeeps oriented subparallel to the Fuegian Andes (Fig. 1). North of the deformation front, a fourth Miocene clastic wedge consists dominantly of subhorizontal strata included in the Cabo Domingo Group (Malumián \& Olivero, 2006; Olivero \& Malumián, 2008). 
Late Cretaceous to Oligocene-earliest Miocene clastic wedges consist dominantly of thick axial and transverse turbidite systems (Olivero et al., 2003; Torres Carbonell \& Olivero, 2012, 2019; Olivero \& Torres Carbonell, 2021). The youngest, early Miocene foredeep fill that forms part of the Cabo Domingo Group consists also of axial and transverse turbidite systems, including spectacular channel-levee complexes and canyon-gully deposits of the Viamonte Formation (Olivero \& Torres Carbonell, 2021). Within the thrust and fold belt, in the Río Irigoyen area, near the trace at the Atlantic coast of the major Magallanes-Fagnano transform fault (Torres Carbonell et al., 2008, 2011), faulted blocks of coarse conglomerate, sandstone and mudstone of the Irigoyen Formation were partly referred to the Pliocene

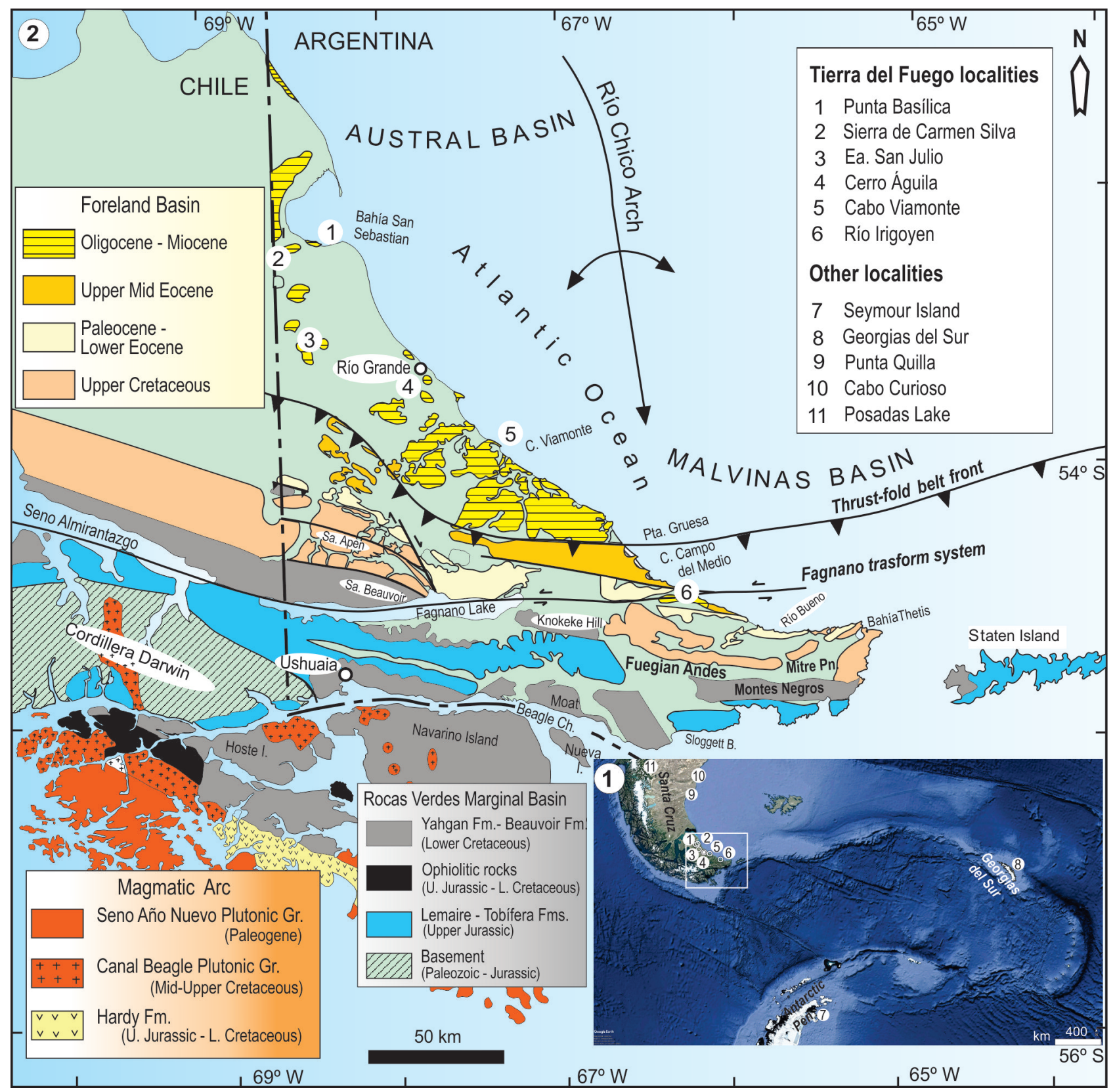

Figure 1.1, Location map showing provenance of the studied material from Tierra del Fuego (1 to 6) and of the material used for comparison (7 to 11) from Antarctica (Seymour Island), Georgias del Sur, and Santa Cruz Province. 2, Geological sketch map of Tierra del Fuego with location of the studied material. 
(Malumián \& Olivero, 2005). The geology and age of the Irigoyen Formation, however, are not well defined. It is probably of early Miocene age according to the calcareous nannoplankton content (Bedoya-Agudelo, 2019). Besides, the foraminiferal assemblage of the Irigoyen Formation is very similar to the Carmen Silva Formation (cf. Malumián \& Olivero, 2005), the age of which is now interpreted as early Miocene (see Olivero \& Torres Carbonell, 2021). The rest of the Cabo Domingo Group exposed in northern and western Tierra del Fuego (Fig. 1), includes shallow marine deltaic deposits of the early Miocene Carmen Silva Formation (Codignotto \& Malumián, 1981; Torres Carbonell \& Olivero, 2019; Olivero \& López Cabrera, 2020), continental deposits of the Miocene Castillo Formation (Codignotto \& Malumián, 1981; Malumián \& Olivero, 2006) and fluvial deposits of the late early Miocene Cullen Formation (Olivero et al., 2015; Olivero \& Torres Carbonell, 2021).

The studied fossil material of the gastropod genus Perissodonta was all recovered from different localities and formations of the Cabo Domingo Group (Figs. 1, 2). Most of the collection comes from different stratigraphic horizons of Carmen Silva Formation exposed in the Sierra Carmen Silva, Estancia San Julio, and Punta Basílica. The rest of the material was collected at several localities from exposures of Viamonte and Irigoyen formations (see the section "Perissodonta fossil-bearing localities").

\section{MATERIAL AND METHODS}

The database for this study consists of gastropod specimens collected by the authors during several summer field seasons between the years 2004 and 2020 in Antarctica, Patagonia (Santa Cruz Province), and Tierra del Fuego. The material from Tierra del Fuego under study is compared with fossil species of Perissodonta from Miocene deposits of Santa Cruz Province, as well as with extant species of Perissodonta georgiana Strebel, 1908 from Georgias del Sur, both housed in the Museo Argentino de Ciencias Naturales "Bernardino Rivadavia", Ciudad Autónoma de Buenos Aires, Argentina. Additional material collected by the authors in the classical localities of the latest Oligocene-earliest Miocene San Julián Formation in the Atlantic coast of Santa Cruz Province (Cabo Curioso, Playa La Mina), the early Miocene Monte León Formation near the towns of Coman- dante Piedrabuena and Puerto Santa Cruz (Punta Quilla at the mouth of the Río Santa Cruz and Mount Entrance) and from the early Miocene El Chacay Formation, near Lago Posadas, were used for comparison with the Perissodonta material from Tierra del Fuego (Fig. 1). However, only the well-preserved material from the Monte León Formation (Piedrabuena and Río Santa Cruz mouth) was included in the morphological analysis. The material from the San Julián and El Chacay formations is incomplete or deformed by lateral compression, thus it is not suitable for measurements. Even though, the El Chacay struthiolariids bear a general resemblance to $P$. ameghinoi they were not included in the morphological analysis. A large collection of Perissodonta (= Struthiolarella) and Antarctodarwinella Zinsmeister, 1976 collected by one of the authors (EBO) from the late mid Eocene to late Eocene La Meseta Formation, Seymour Island, Antarctica was also available for comparison with the Miocene material.

For the study of the variability in Perissodonta we follow the approaches used by most of the researchers that have studied fossil species of this genus. In addition to the format used by Ihering $(1897,1907)$ and Ortmann $(1902)$, we follow in particular the one used by Steinmann \& Wilkens (1908) and Camacho \& Zinsmeister (1989) to group and analyze morphological characters of the shell of Perissodonta. This procedure has proven useful to compare the species and variation of morphological characters described in these studies with our material. Basically, used morphological terms and measurements include: shell height $(\mathrm{H})$; shell width (W); spire height (Sh); last whorl height (Lwh); proportion between $\mathrm{Sh}$ and $\mathrm{H}$, defined as $100 . \mathrm{Sh} / \mathrm{H}$; number and strength of spiral cords, spiral threads, and tubercles (see Fig. 3.1).

The studied material is housed at the paleontological collections of the Centro Austral the Investigaciones Científicas (CADIC-CONICET), Ushuaia, Argentina, under the numbers CADIC PI 610-623. The material housed at the Museo Argentino de Ciencias Naturales "Bernardino Rivadavia", Ciudad Autónoma de Buenos Aires is identified with the acronyms MACN-Pi 763 and MACN-In 36298, 18955, 18953. 


\section{PERISSODONTA FOSSIL-BEARING LOCALITIES IN TIERRA} DEL FUEGO

\section{Carmen Silva Formation}

In the Carmen Silva Formation, fossiliferous beds with Perissodonta are recorded in both the Sierra Carmen Silva beds and the Punta Basílica beds. These beds are interpreted as distinct coarsening upwards delta successions (Torres Carbonell \& Olivero, 2019) and were differentiated as informal units of the Carmen Silva Formation by Olivero \& López Cabrera (2020).

Sierra de Carmen Silva beds. These beds include two fossil localities. At one locality the studied fossils come from the upper part of the prodelta mudstones exposed in the Sierra de Carmen Silva, just east of the Chilean-Argentinean border (Fig. 1, locality 2, point 135: 53 19' 38.1" S, $68^{\circ} 35^{\prime}$ 32" W; see Torres Carbonell \& Olivero, 2019). At this locality Perissodonta ameghinoi is associated with abundant specimens of the genus Turritella Lamarck, 1799 (Fig. 2.1). The two species are represented by well-preserved shells dispersed in mudstone, with no sign of reworking or reorientation by currents, and are interpreted as an autochthonous association. At the second locality the specimens lie in cross-stratified conglomerate, coarse-grained sandstones and pebbly sandstones exposed in quarries and artificial cuts along the road to Estancia San Julio (Fig. 1, locality 3.

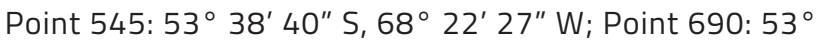
39' 51.2" S, $68^{\circ} 29^{\prime} 6.8^{\prime \prime}$ W). These coarse-grained beds probably represent proximal prodelta and distributary mouth bars (cf. Feldmann et al., 2011; Torres Carbonell \& Olivero, 2019). Shell reworking by currents is evident and Perissodonta forms part of a para-autochthonous-allochthonous mixture of partially broken or relatively complete shells, commonly concentrated together with bivalves, gastropods and crustacean decapods in lenses within the conglomerate and coarse-grained sandstones (Fig. 2.2).

Punta Basílica beds. These beds includes fossil gastropods such as the relatively abundant Turritella sp., Perissodonta ameghinoi, specimens of the bivalve genus Barnea Risso, 1826 in life position, crustacean decapods, barnacles, solitary corals and leaves of Nothofagus. Fossils are generally well-preserved in fine-grained silty sandstone and fine- to medium-grained sandstone or else are represented by scattered and partially broken shells concentrated in fine-grained conglomerate (Fig. 1; locality 1 (PB 731), $53^{\circ} 18^{\prime} 10^{\prime \prime} \mathrm{S}, 68^{\circ}$ $24^{\prime} 48.9^{\prime \prime}$ W). Fossiliferous beds form part of steeply inclined delta-front clinoform deposits (Fig. 2.3-4). In particular, the stratigraphically older clinoform deposits record wave ripples and wave-ripple cross-lamination and crossstratified sandstones forming large compound dunes and tidal bars (Olivero \& López Cabrera, 2020).

\section{Viamonte Formation}

Fossil mollusks, including Perissodonta ameghinoi, are recorded in two of the main architectural elements (Fig. 2.5-7) of the deep-water turbidite systems recognized in the Viamonte Formation (see Olivero \& Torres Carbonell, 2021). In the transverse turbidite system Perissodonta, other gastropods, bivalves, corals, barnacles, and crustacean decapods are recorded in fine-grained conglomerates forming part of the element gullies and other slope deposits of this system. In the axial turbidite system Perissodonta-commonly associated with dense concentration of Turritella sp.-is recorded also in heterolithic slumped beds and fine-grained debris flows, at the base of the architectural element channel belt of this system (Olivero \& Torres Carbonell, 2021). In both architectural elements, the lithology is well-cemented and very hard, rendering impossible the recovery of fossil material adequate for measurement. Only field photographs (Fig. 2.6-7) and a few internal molds or broken specimens (Locality 5, point $16454^{\circ} 02^{\prime} 32.5^{\prime \prime}$ S, 67 19' 39.9" W) are available.

Additional specimens of Perissodonta ameghinoi were also recorded in the Cerro Águila conglomerate in association with bivalves, other gastropods, solitary corals, and crustacean decapods (Locality 4, 53 50' 11.15" S, 67 47' 31.85" W). The stratigraphic relationship of the Cerro Águila channelized conglomerates is not clear, but together with the Cabo Peñas conglomerates it probably forms part of the transverse turbidite system of the Viamonte Formation (cf. Olivero \& Torres Carbonell, 2021).

\section{Irigoyen Formation}

The ichnology and sedimentology of the shallow-marine deposits of the Irigoyen Formation are presently under study by the authors. However, they can be generally characterized as inner shelf deposits (Malumián \& Olivero, 2005) 
that reach a minimum thickness of $c a .65 \mathrm{~m}$. The lower part, including a thick, slumped horizon with abundant reworked carbonized logs, gastropods, bivalves and corals originated below wave and tidal influence. This horizon is covered in onlap relationship by parallel-laminated and cross-bedded fine-grained sandstone beds that grade upwards to silty very fine-grained bioturbated sandstones and to cross-stratified sandstones defining shallow channels. The top of the succession is marked by fossiliferous, cross-stratified channelized conglomerates (Fig. 2.8). The gastropod Perissodonta is relatively abundant in the basal slump horizon and in the upper channelized conglomerate (Fig. 1 ; locality 6 , points $\left.841,845,54^{\circ} 30^{\prime} 37.2^{\prime \prime} \mathrm{S}, 66^{\circ} 17^{\prime} 55.5^{\prime \prime} \mathrm{W}\right)$.

\section{THE RECORD OF MIOCENE PERISSODONTA IN PATAGONIA AND TIERRA DEL FUEGO}

Since their earliest mention in the mid-19 ${ }^{\text {th }}$ century, struthiolariid gastropods from the Cenozoic of Patagonia, Tierra del Fuego and Georgias del Sur were initially included in the genus Struthiolaria Lamarck, 1816 and later in Struthiolarella Steinmann \& Wilckens, 1908, but presently these struthiolariids are assigned to the genus Perissodonta (see Systematic Paleontology). The first known struthiolariid from Patagonia is Perissodonta ornata, that was described by Sowerby while studying the material collected by Darwin (1846) from marine deposits of the Monte León Formation, Santa Cruz (see Griffin \& Nielsen, 2008). The diagnosis of $P$. ornata includes a canaliculated suture and two (rarely three) strong cords in the last whorl. These last two characters and the small size of the specimen are very distinctive and characteristic of $P$. ornata (personal observation of the authors in the type locality). Philippi (1887) erected Perissodonta chilensis (Philippi, 1887) from Matanzas, Navidad (Chile), based on the nodular aspect of the tubercles and five or six spiral cords in the last whorl (see also Nielsen, 2005). Ihering (1897), studying specimens of "Struthiolaria" from the Monte León Formation erected Perissodonta ameghinoi. Its original diagnostic characters included 15 sharp tubercles, eight or nine narrow spiral threads, and five or six spiral cords in the last whorl. He also noted the close similarities in ornamentation shared by $P$. chilensis and $P$. ameghinoi. Additional species and varieties subsequently elevated to the specific rank were established by Ortmann (1902) and
Camacho \& Zinsmeister (1989) from the Miocene of Santa Cruz Province. These include Perissodonta multinodosa, Perissodonta cuevensis, and Perissodonta patagoniensis. The latter, however, is considered herein as a synonym of $P$. ornata due to its characteristic canaliculated suture and two strong cords. Ortmann (1902) also erected Perissodonta hatcherifrom Eocene deposits of Punta Arenas, Chile, which carries spiral cords equally developed all over the shell surface, a character by which it differs from the rest of the species of Perissodonta.

Earliest mentions of fossil Perissodonta from Tierra del Fuego are from the Carmen Silva Formation and correspond to $P$. fueguina (cf. Camacho \& Zinsmeister, 1989) and $P$. ameghinoi described by Steinmann \& Wilckens (1908). The latter was designated the type species of the newly erected genus Struthiolarella, but the genus is now considered a junior synonym of Perissodonta (see Systematic Paleontology). Malumián et al. (1978) recorded Perissodonta densestriata from the locality of Estancia La Federica (Carmen Silva Formation) and Camacho \& Zinsmeister (1989) reported $P$. fueguina from the same locality.

The material from Tierra del Fuego assigned to $P$. ameghinoi by Steimann \& Wilckens (1908) included four specimens, collected from outcrops located in the northern part of the island named Sierra de Carmen Silva, Barranca de Carmen Silva or San Sebastián (i.e., Punta Basílica), and the Atlantic coast between Punta Sinai and Cabo Domingo. They stressed the strong variability of the spiral sculpture, the height of the spire, and characters of the aperture and callus. Interestingly, Steinmann \& Wilckens (1908) included the extant Perissodonta mirabilis (Smith, 1875) from Kerguelen, as a synonym of the new genus Struthiolarella not noticing, however, that $S$. mirabilis is the type species of the genus Perissodonta (cf. Powell, 1951; Griffin \& Nielsen, 2008; López Cabrera \& Olivero, 2018).

Species described so far from Patagonia show also a large variability of the shell morphology, such as spire height and number of threads, cords and tubercles. The material described by Ortmann $(1902)$ and Ihering $(1897,1907)$ was compiled by Camacho \& Zinsmeister (1989) in a systematic study. Although in that study they show intermediate forms in some species, such as P. ameghinoi and P. multinodosa, particularly regarding the intergradation in the number and 

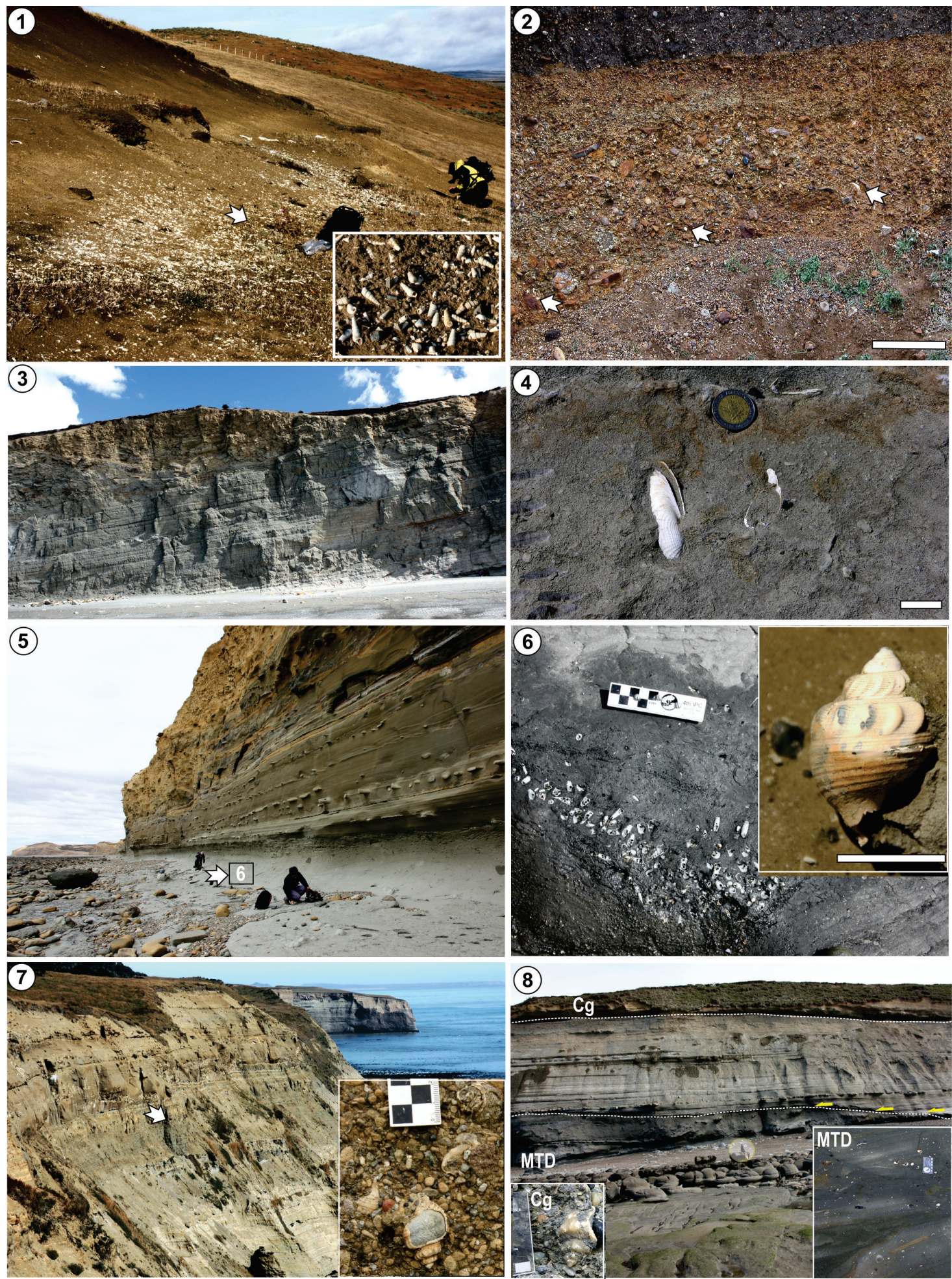

Figure 2. Localities with the studied Perissodonta ameghinoifrom Tierra del Fuego. 1-4, Carmen Silva Formation. 1, Sierra Carmen Silva, locality 2, point 135, with abundant gastropods (inset) in some horizons (white arrow); 2, Quarry near Estancia San Julio, locality 3, point 545, scale bar 40 cm; 3, Punta Basílica beds, locality 1, point PB 731, height of cliff c. 20 m, with fossiliferous horizons; 4, note Barnea sp. in living position, scale bar 2 cm. 5-7, Viamonte Formation. 5-6, locality 5, point 164, channel-levee system of the axial channel belt (5), preserving abundant turritellids and Perissodonta ameghinoi (inset in 6, scale bar $1 \mathrm{~cm}$ ) in slumped, heterolithic blocks and debris flow deposits (6); 7 , gully and slope facies of the transverse system, with fossiliferous conglomerates (arrow) with Perissodonta ameghinoi (inset). 8, Irigoyen Formation, locality 6, points 841, 845, note large mass transport deposit (MTD) covered in onlap relationship (yellow arrows) by fine-grained silty sandstones and mudstones, and coarse-grained conglomerate $(\mathrm{Cg})$ on top of the cliff, circled person for scale. The MTD and conglomerate both preserve Perissodonta ameghinoi (insets, scale in cm). 
shape of tubercles, they used these characters to differentiate the species. The study of intraspecific variability in the species of Perissodonta restricted to Santa Cruz is beyond the scope of this study. Instead, we restrict our study to the analysis of the variability in the Perissodonta species so far mentioned or described from Tierra del Fuego, which includes P. ameghinoi, P. fueguina, and P. densestriata, which we suggest can be reunited in the single, plastic species $P$. ameghinoi.

\section{MORPHOLOGICAL VARIABILITY IN THE FUEGIAN PERISSODONTA}

The general morphology of Perissodonta specimens from Tierra del Fuego is characterized by medium to large size, globose (W/H: 0.9) to sub-globose $(\mathrm{W} / \mathrm{H}: 0.6)$ shells with a convex to squarish or scalariform outline; highly variable proportion between Sh and $\mathrm{H}$ (average $33.0 \%$, range 10.149.5\%); sub-oval shell aperture, widening adapically; inner lip with thick inductura; short siphonal canal; and impressed suture. The sculpture of the shell consists of strong spiral cords in the last whorl; narrow spiral threads are present in the adapical part of the whorl; and prosocline tubercles.

To study the variability of the shell morphology in Perissodonta we found useful the representation of the ratios between: 1) the spire height (Sh) and the total shell length $(H)$, thus the ratio $\mathrm{Sh} / \mathrm{H}$ is a measure of the relative height of the spire, and 2) between the shell width (W) and the last whorl height (Lwh), thus the ratio W/Lwh measures the relative width of the shell. In the studied material of $P$. ameghinoi from Tierra del Fuego and Santa Cruz, the ratio $\mathrm{Sh} / \mathrm{H}$ varies within 0.5 and 0.1 , mean value 0.3 , whereas the ratio $\mathrm{W} / \mathrm{L}$ wh varies between 1.2 and 0.7 , mean value 1.0 (Tab. 1). The plot of these ratios shows the total morphospace covered by the studied gastropods, which varies from relatively high spire-wide shells to the right, to relatively low spire-narrow shells to the left (Fig. 3.1). Other plots depict the variability of the shell shape, using the parameters $\mathrm{H}$ and $\mathrm{W}$ (Fig. 3.2), and the sculpture, plotting the number of cords, threads, and tubercles at different shell heights (Fig. 3.3). These plots (Fig. 3.2-3) include Perissodonta ameghinoi from different formations in Tierra del Fuego, as well as P. ameghinoi and P. ornata from the Monte León Formation, Santa Cruz Province.
In P. ameghinoifrom Tierra del Fuego and Santa Cruz, the set of parameters used to characterize the morphology varies continuously, showing no distinct clusters in the proportions of the spire height relative to total shell height $(\mathrm{Sh} / \mathrm{H})$, or in the maximum shell width relative to the last whorl height (W/Lwh; Fig. 3.1). The same pattern is shown by the plot of the shell length and width (Fig. 3.2). A similar lack of distinct clusters in P. ameghinoi from Tierra del Fuego and Santa Cruz is seen in the plot of sculptural characters, including spiral cords, spiral threads, and number of tubercles (Fig. 3.3). Conversely, the morphological and sculptural parameters of $P$. ornata show a distinct cluster of points that clearly separates this species from P. ameghinoi (Fig. 3.2).

In order to better illustrate the range of variability in the Perissodonta specimens from Tierra del Fuego we have chosen eight representative morphological variants, which were selected according to their characteristic morphological and ornamental characters. These eight morphological variants (Fig. 4-5) are distinguished by a blue square in the plot of Figure 3 and their distinguishing characters are briefly described below.

\section{Morphological variant 1}

Shell sub-globose, consisting of six whorls characterized by a squarish outline. Dimensions are $37.9 \mathrm{~mm}$ height, 29 $\mathrm{mm}$ width, and spire reaching $36 \%$ of total height. Thirteen spiral threads, shoulder of the sutural ramp coronate with 12-13 pointed tubercles. The last whorl bears five to six spiral cords followed by seven to eight spiral threads up to the fasciole (Fig. 4.1-3).

\section{Morphological variant 2}

The shell is sub-globose, proportionally less wide than morphological variant 1 , whorls are slightly squarish in outline. Dimensions are $44 \mathrm{~mm}$ height, $25 \mathrm{~mm}$ width, and spire reaching $39 \%$ of the total height. Thirteen spiral threads, shoulder of the sutural ramp coronate with 14 slightly pointed tubercles. The last whorl bears five spiral cords of equal size followed by seven spiral threads up to the aperture and over the fasciole (Fig. 4.4).

\section{Morphological variant 3}

The shell is globose, whorls are convex in outline. 


\begin{tabular}{|c|c|c|c|c|c|c|c|c|c|c|c|c|c|c|}
\hline \multicolumn{15}{|c|}{ Perissodonta ameghinoi from Tierra del Fuego } \\
\hline CADIC PI & ID & $\mathrm{H}$ & W & Bwh & Sh & $\%$ spire & W/Bwh & $\mathrm{Sh} / \mathrm{H}$ & W/H & Sh/Bwh & Cords & Threads & Tubercles & Locality \\
\hline 610 & 1 & 39.1 & 25.6 & 29.1 & 10.0 & 25.6 & 0.9 & 0.3 & 0.7 & 0.3 & 7.0 & 13.0 & 12.0 & 690 \\
\hline 610 & 2 & 38.8 & 25.0 & 25.4 & 13.4 & 34.5 & 1.0 & 0.3 & 0.6 & 0.5 & 4.0 & 12.0 & 13.0 & 690 \\
\hline 610 & 3 & 52.0 & 34.5 & 41.0 & 11.0 & 21.2 & 0.8 & 0.2 & 0.7 & 0.3 & 5.0 & 12.0 & 13.0 & 690 \\
\hline 610 & 12 & 35.3 & 24.2 & 23.5 & 11.8 & 33.4 & 1.0 & 0.3 & 0.7 & 0.5 & 7.0 & 13.0 & 12.0 & 690 \\
\hline 610 & 13 & 44.1 & 35.0 & 32.5 & 11.6 & 26.3 & 1.1 & 0.3 & 0.8 & 0.4 & 6.0 & 13.0 & 12.0 & 690 \\
\hline 610 & 14 & 36.6 & 27.2 & 25.1 & 11.5 & 31.4 & 1.1 & 0.3 & 0.7 & 0.5 & 7.0 & 13.0 & 12.0 & 690 \\
\hline 610 & 15 & 44.2 & 34.0 & 37.5 & 6.7 & 15.2 & 0.9 & 0.2 & 0.8 & 0.2 & 5.0 & 13.0 & 12.0 & 690 \\
\hline 610 & 19 & 37.7 & 27.3 & 24.2 & 13.5 & 35.8 & 1.1 & 0.4 & 0.7 & 0.6 & 6.0 & 12.0 & 12.0 & 690 \\
\hline 610 & 26 & 35.9 & 23.2 & 22.3 & 13.6 & 37.9 & 1.0 & 0.4 & 0.6 & 0.6 & 6.0 & 12.0 & 12.0 & 690 \\
\hline 610 & 30 & 42.7 & 37.0 & 31.0 & 11.7 & 27.4 & 1.2 & 0.3 & 0.9 & 0.4 & 5.0 & 12.0 & 12.0 & 690 \\
\hline 610 & 35 & 34.2 & 25.8 & 29.9 & 4.3 & 12.6 & 0.9 & 0.1 & 0.8 & 0.1 & 5.0 & 12.0 & 12.0 & 690 \\
\hline 610 & 39 & 32.7 & 24.6 & 29.4 & 3.3 & 10.1 & 0.8 & 0.1 & 0.8 & 0.1 & 7.0 & 13.0 & 12.0 & 690 \\
\hline 610 & 33 & 43.7 & 32.2 & 29.7 & 14.0 & 32.0 & 1.1 & 0.3 & 0.7 & 0.5 & 5.0 & 13.0 & 12.0 & 690 \\
\hline 611 & 6 & 38.3 & 25.2 & 24.6 & 13.7 & 35.8 & 1.0 & 0.4 & 0.7 & 0.6 & 7.0 & 13.0 & 13.0 & 545 \\
\hline 611 & 4 & 36.4 & 23.5 & 21.3 & 15.1 & 41.5 & 1.1 & 0.4 & 0.6 & 0.7 & 7.0 & 12.0 & 12.0 & 545 \\
\hline 611 & 8 & 36.8 & 25.7 & 25.7 & 11.1 & 30.2 & 1.0 & 0.3 & 0.7 & 0.4 & 5.0 & & 12.0 & 545 \\
\hline 611 & 9 & 47.6 & 34.7 & 32.9 & 14.7 & 30.9 & 1.1 & 0.3 & 0.7 & 0.4 & 6.0 & & 13.0 & 545 \\
\hline 611 & 10 & 33.1 & 21.1 & 21.6 & 11.5 & 34.7 & 1.0 & 0.3 & 0.6 & 0.5 & 7.0 & 13.0 & 13.0 & 545 \\
\hline 611 & 11 & 37.5 & 22.4 & 21.2 & 16.3 & 43.5 & 1.1 & 0.4 & 0.6 & 0.8 & 6.0 & 13.0 & 13.0 & 545 \\
\hline 611 & 16 & 40.0 & 24.4 & 33.1 & 6.9 & 17.3 & 0.7 & 0.2 & 0.6 & 0.2 & 6.0 & 13.0 & 13.0 & 545 \\
\hline 611 & 17 & 43.5 & 28.2 & 27.2 & 16.3 & 37.5 & 1.1 & 0.4 & 0.7 & 0.6 & 5.0 & 13.0 & 13.0 & 545 \\
\hline 611 & 18 & 42.0 & 24.8 & 25.9 & 16.1 & 38.3 & 1.0 & 0.4 & 0.6 & 0.6 & 5.0 & 12.0 & 12.0 & 545 \\
\hline 611 & 20 & 43.4 & 28.9 & 30.0 & 13.4 & 30.9 & 1.0 & 0.3 & 0.7 & 0.4 & 7.0 & 13.0 & 12.0 & 545 \\
\hline 611 & 21 & 38.2 & 28.9 & 24.9 & 13.3 & 34.8 & 1.2 & 0.3 & 0.8 & 0.5 & 6.0 & 13.0 & 12.0 & 545 \\
\hline 611 & 22 & 42.2 & 32.7 & 29.3 & 12.9 & 30.6 & 1.1 & 0.3 & 0.8 & 0.4 & 6.0 & 13.0 & 12.0 & 545 \\
\hline 611 & 23 & 43.8 & 29.9 & 35.4 & 8.4 & 19.2 & 0.8 & 0.2 & 0.7 & 0.2 & 7.0 & 13.0 & 13.0 & 545 \\
\hline 611 & 24 & 42.5 & 27.4 & 28.1 & 14.4 & 33.9 & 1.0 & 0.3 & 0.6 & 0.5 & 6.0 & 13.0 & 12.0 & 545 \\
\hline 611 & 25 & 41.5 & 27.4 & 29.9 & 11.6 & 28.0 & 0.9 & 0.3 & 0.7 & 0.4 & 6.0 & 10.0 & 12.0 & 545 \\
\hline 611 & 28 & 37.3 & 23.7 & 24.5 & 12.8 & 34.3 & 1.0 & 0.3 & 0.6 & 0.5 & 6.0 & 12.0 & 12.0 & 545 \\
\hline 611 & 29 & 35.4 & 22.0 & 22.1 & 13.3 & 37.6 & 1.0 & 0.4 & 0.6 & 0.6 & 6.0 & 13.0 & 12.0 & 545 \\
\hline 611 & 31 & 46.6 & 31.0 & 32.0 & 14.6 & 31.3 & 1.0 & 0.3 & 0.7 & 0.5 & 7.0 & 12.0 & 12.0 & 545 \\
\hline 611 & 32 & 32.0 & 19.8 & 19.8 & 12.2 & 38.1 & 1.0 & 0.4 & 0.6 & 0.6 & 6.0 & 10.0 & 12.0 & 545 \\
\hline 611 & 34 & 48.0 & 27.2 & 28.0 & 20.0 & 41.7 & 1.0 & 0.4 & 0.6 & 0.7 & 7.0 & 10.0 & 12.0 & 545 \\
\hline 611 & 36 & 42.2 & 27.3 & 28.3 & 13.9 & 32.9 & 1.0 & 0.3 & 0.6 & 0.5 & 5.0 & & 13.0 & 545 \\
\hline 611 & 38 & 37.4 & 24.4 & 23.6 & 13.8 & 36.9 & 1.0 & 0.4 & 0.7 & 0.6 & 6.0 & 11.0 & 12.0 & 545 \\
\hline 611 & 40 & 31.6 & 23.9 & 25.5 & 6.1 & 19.3 & 0.9 & 0.2 & 0.8 & 0.2 & 6.0 & 12.0 & 12.0 & 545 \\
\hline 611 & 41 & 47.9 & 28.8 & 37.0 & 10.9 & 22.8 & 0.8 & 0.2 & 0.6 & 0.3 & 6.0 & 13.0 & 12.0 & 545 \\
\hline 611 & 42 & 38.6 & 26.2 & 24.4 & 14.2 & 36.8 & 1.1 & 0.4 & 0.7 & 0.6 & 6.0 & 12.0 & 12.0 & 545 \\
\hline 611 & 43 & 48.3 & 27.0 & 24.4 & 23.9 & 49.5 & 1.1 & 0.5 & 0.6 & 1.0 & 6.0 & 9.0 & 12.0 & 545 \\
\hline 611 & 44 & 44.1 & 29.4 & 27.2 & 16.9 & 38.3 & 1.1 & 0.4 & 0.7 & 0.6 & 6.0 & 13.0 & & 545 \\
\hline 611 & 46 & 32.2 & 20.1 & 22.2 & 10.0 & 31.1 & 0.9 & 0.3 & 0.6 & 0.5 & 6.0 & 12.0 & 12.0 & 545 \\
\hline 611 & 47 & 28.8 & 19.3 & 17.5 & 11.3 & 39.2 & 1.1 & 0.4 & 0.7 & 0.6 & 5.0 & 9.0 & 12.0 & 545 \\
\hline 611 & 48 & 27.9 & 20.9 & 17.2 & 10.7 & 38.4 & 1.2 & 0.4 & 0.7 & 0.6 & & & & 545 \\
\hline 611 & 49 & 33.6 & 20.9 & 21.6 & 12.0 & 35.7 & 1.0 & 0.4 & 0.6 & 0.6 & 6.0 & & 12.0 & 545 \\
\hline 611 & 50 & 38.3 & 24.5 & 23.5 & 14.8 & 38.6 & 1.0 & 0.4 & 0.6 & 0.6 & 6.0 & 13.0 & 12.0 & 545 \\
\hline 611 & 51 & 38.4 & 24.9 & 24.1 & 14.3 & 37.2 & 1.0 & 0.4 & 0.6 & 0.6 & 5.0 & 10.0 & 12.0 & 545 \\
\hline 611 & 52 & 40.4 & 25.5 & 25.5 & 14.9 & 36.9 & 1.0 & 0.4 & 0.6 & 0.6 & 6.0 & 9.0 & 13.0 & 545 \\
\hline 611 & 53 & 42.5 & 27.9 & 27.9 & 14.6 & 34.4 & 1.0 & 0.3 & 0.7 & 0.5 & 6.0 & 12.0 & 12.0 & 545 \\
\hline
\end{tabular}




\section{TABLE 1 - Continuation}

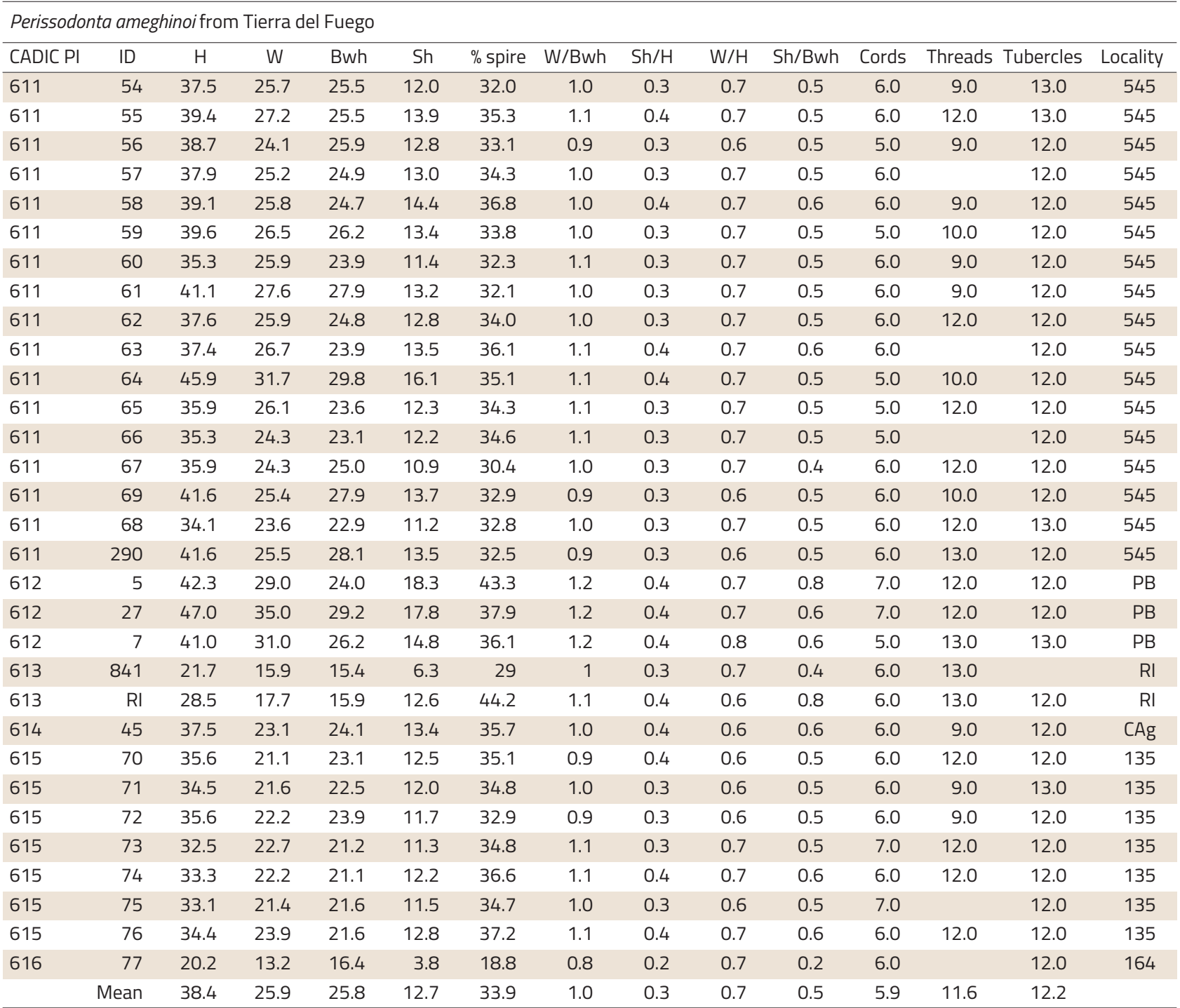

P. ameghinoi from Santa Cruz. Monte Entrance

\begin{tabular}{lrrrrrrrrrrrrrr}
\hline CADIC PI & ID & $\mathrm{H}$ & W & Bwh & Sh & \% spire & W/Bwh & Sh/H & W/H & Sh/Bwh & Cords & Threads Tubercles & Locality \\
\hline 617 & 1 & 53.1 & 25.1 & 28.1 & 25.0 & 47.1 & 0.9 & 0.5 & 0.5 & 0.9 & 5.0 & 9.0 & 12.0 & E21 \\
617 & 2 & 47.2 & 26.6 & 27.4 & 19.8 & 41.9 & 1.0 & 0.4 & 0.6 & 0.7 & 6.0 & 9.0 & 18.0 & E21 \\
617 & 3 & 41.6 & 25.5 & 25.8 & 15.8 & 38.0 & 1.0 & 0.4 & 0.6 & 0.6 & 5.0 & 9.0 & 15.0 & E21 \\
617 & 4 & 44.4 & 25.5 & 27.8 & 16.6 & 37.4 & 0.9 & 0.4 & 0.6 & 0.6 & 5.0 & 9.0 & 12.0 & E21 \\
617 & 5 & 42.4 & 23.6 & 25.1 & 17.3 & 40.8 & 0.9 & 0.4 & 0.6 & 0.7 & 5.0 & 9.0 & 12.0 & E21 \\
617 & 6 & 58.8 & 34.4 & 33.7 & 25.1 & 42.7 & 1.0 & 0.4 & 0.6 & 0.7 & 5.0 & 9.0 & 18.0 & E21 \\
& Mean & 47.9 & 26.8 & 28.0 & 19.9 & 41.3 & 1.0 & 0.4 & 0.6 & 0.7 & 5.2 & 9.0 & 14.5 & \\
\hline
\end{tabular}

$P$. ornata from Piedrabuena and Monte Entrance

\begin{tabular}{|c|c|c|c|c|c|c|c|c|c|c|c|c|c|c|}
\hline CADIC PI & ID & $\mathrm{H}$ & W & Bwh & Sh & \% spire & W/Bwh & $\mathrm{Sh} / \mathrm{H}$ & W/H & Sh/Bwh & Cords & Threads & Tubercles & Locality \\
\hline 618 & 1.0 & 22.7 & 9.6 & 13.1 & 9.6 & 42.3 & 0.7 & 0.5 & 0.5 & 0.9 & 2.0 & 9.0 & 12.0 & R3 1 \\
\hline 618 & 2.0 & 18.7 & 7.5 & 11.2 & 7.5 & 40.1 & 0.7 & 0.4 & 0.6 & 0.7 & 2.0 & 9.0 & 12.0 & R3 2 \\
\hline \multirow[t]{2}{*}{618} & 6.0 & 25.0 & 11.0 & & & & & & 0.4 & & 2.0 & 12.0 & 18.0 & * \\
\hline & Mean & 22.1 & 9.4 & 12.2 & 8.6 & 41.2 & 0.7 & 0.4 & 0.5 & 0.8 & 2.0 & 10.0 & 14.0 & \\
\hline
\end{tabular}



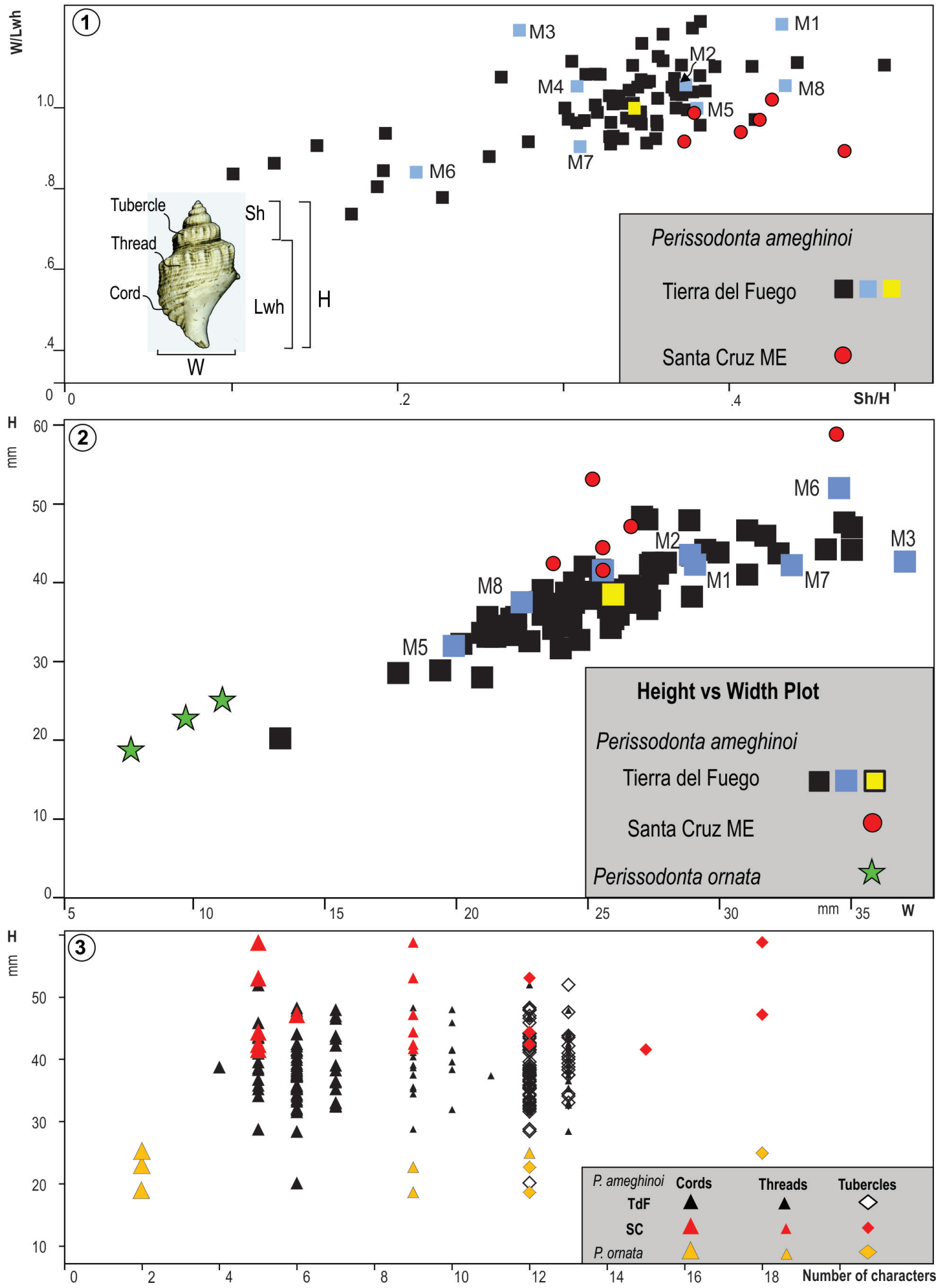

Figure 3. Plot of morphological characters in Perissodonta. 1, plot of the ratios W/Lwh and Sh/H in P. ameghinoi from Tierra del Fuego (squares) and Mount Entrance, Santa Cruz (red circles). Color fill of squares represents values of actual specimens (black), the mean value (yellow), and representative values for indicated morphological variants (M) (light blue). Note continuity and superposition of the ratios in P. ameghinoi specimens from Tierra del Fuego and Santa Cruz, suggesting ample intraspecific variability. Inset indicates the meaning of W, Lwh, H, Sh, and ornamental characters. 2-3, combined plot of $\mathrm{H}$ vs. W (B) and $\mathrm{H}$ vs. the number (C) of various ornamental characters (cords, threads, and tubercles) in P. ameghinoi and P. ornata, the latter includes P. patagoniensis of Camacho \& Zinsmeister (1989). Note that only P. ornata occupies a distinct morphospace in both 2 and 3 plots, See text for further explanation. 
Dimensions are height $42.4 \mathrm{~mm}$, width $25.6 \mathrm{~mm}$, and low spire reaching $27 \%$ of total height. Thirteen spiral threads, the shoulder of the sutural ramp bear 13 convex tubercles. The last whorl bears five spiral cords of equal size and five to six narrower ones up to the aperture and over the fasciole (Fig. 4.5-6).

\section{Morphological variant 4}

The shell is sub-globose, proportionally less wide than morphological variant 3 , with whorls slightly convex in outline. Dimensions are height $44 \mathrm{~mm}$, width $23.6 \mathrm{~mm}$, and spire reaching $32 \%$ of total height. Thirteen spiral threads, the shoulder of the sutural ramp bearing 12 slightly pointed tubercles. The last whorl bears six spiral cords of equal size and seven narrower threads up to the aperture and over the fasciole (Fig. 4.7-8).

\section{Morphological variant 5}

The shell is sub-globose with whorls squarish in outline. Dimensions are height $32 \mathrm{~mm}$, width $17.7 \mathrm{~mm}$, and relatively high spire reaching $41 \%$ of the total height. Thirteen spiral threads, the shoulder of the sutural ramp bears 12 pointed tubercles. The last whorl bears seven spiral cords, the two first ones narrower than the rest, followed by four strong cords of equal size and one narrower cord. There are five narrow threads up to the aperture and over the fasciole (Fig. 4.9).

\section{Morphological variant 6}

The shell is sub-globose with slightly convex whorls. Dimensions are height $50.2 \mathrm{~mm}$, width $31 \mathrm{~mm}$, and spire reaching $36 \%$ of total height. Twelve spiral threads, the shoulder of the sutural shelf is coronate bearing 13 slightly pointed tubercles. The last whorl bears five strong spiral cords, the first one wider than the rest, followed by at least five narrower spiral threads over the fasciole (Fig. 5.1).

\section{Morphological variant 7}

The shell is globose, with whorls slightly convex in outline. Dimensions are height $42.2 \mathrm{~mm}$, width $26.6 \mathrm{~mm}$, and spire reaching $29 \%$ of the total height. Twelve spiral threads, the shoulder of the sutural shelf bear 12-13 pointed tubercles. The last whorl bears six spiral cords of equal size and eight narrower threads up to the aperture and over the fasciole (Fig. 5.2-3).

\section{Morphological variant 8}

The small shell is globose, with whorls slightly convex in outline. Dimensions are height $30.4 \mathrm{~mm}$, width $25.5 \mathrm{~mm}$, and low spire reaching 33\% of total height. Thirteen spiral threads, the shoulder of the sutural ramp bears 14 nodose tubercles. The last whorl bears eight spiral cords of equal size that are followed by seven to eight narrower cords decreasing in size up to the aperture and over the fasciole (Fig. 5.4).

\section{SYSTEMATIC PALEONTOLOGY}

\author{
Superfamily STROMBOIDEA Rafinesque, 1815 \\ Family STRUTHIOLARIIDAE Fischer, 1884
}

Genus Perissodonta Martens, 1878

Type species. Struthiolaria mirabilis Smith, 1875 by monotypy; Recent, Kerguelen Islands, France.

Remarks. When Steinmann \& Wilckens (1908) created Struthiolarella to accommodate species previously included in Struthiolaria Lamarck, 1816-but characterized differently by transversal sculpture in the older whorls-they included the extant Struthiolaria mirabilis Smith, 1875 in Struthiolarella. They did not notice, however, that $S$. mirabilis was previously designated the type species of the newly erected genus Perissodonta Martens, 1878, thus Struthiolarella is now considered invalid and it is a junior synonym of Perissodonta. Steinmann \& Wilckens (1908) considered, among other characters, the presence of strong cords in the last whorl to differentiated Struthiolarella from the apparently uniform strength of the spiral cords in Perissodonta (see also Marwick, 1924). However the shell sculpture of both genera shows similar variability in strength of spirals cords on the last whorl surface, as we have observed in extant specimens of Perissodonta georgiana Strebel, 1908 (Fig. 6) from Islas Georgias del Sur, housed in the collection of the Museo Argentino de Ciencias Naturales, CABA, Argentina (see also Beu, 2009 and references therein). P. georgiana is either 

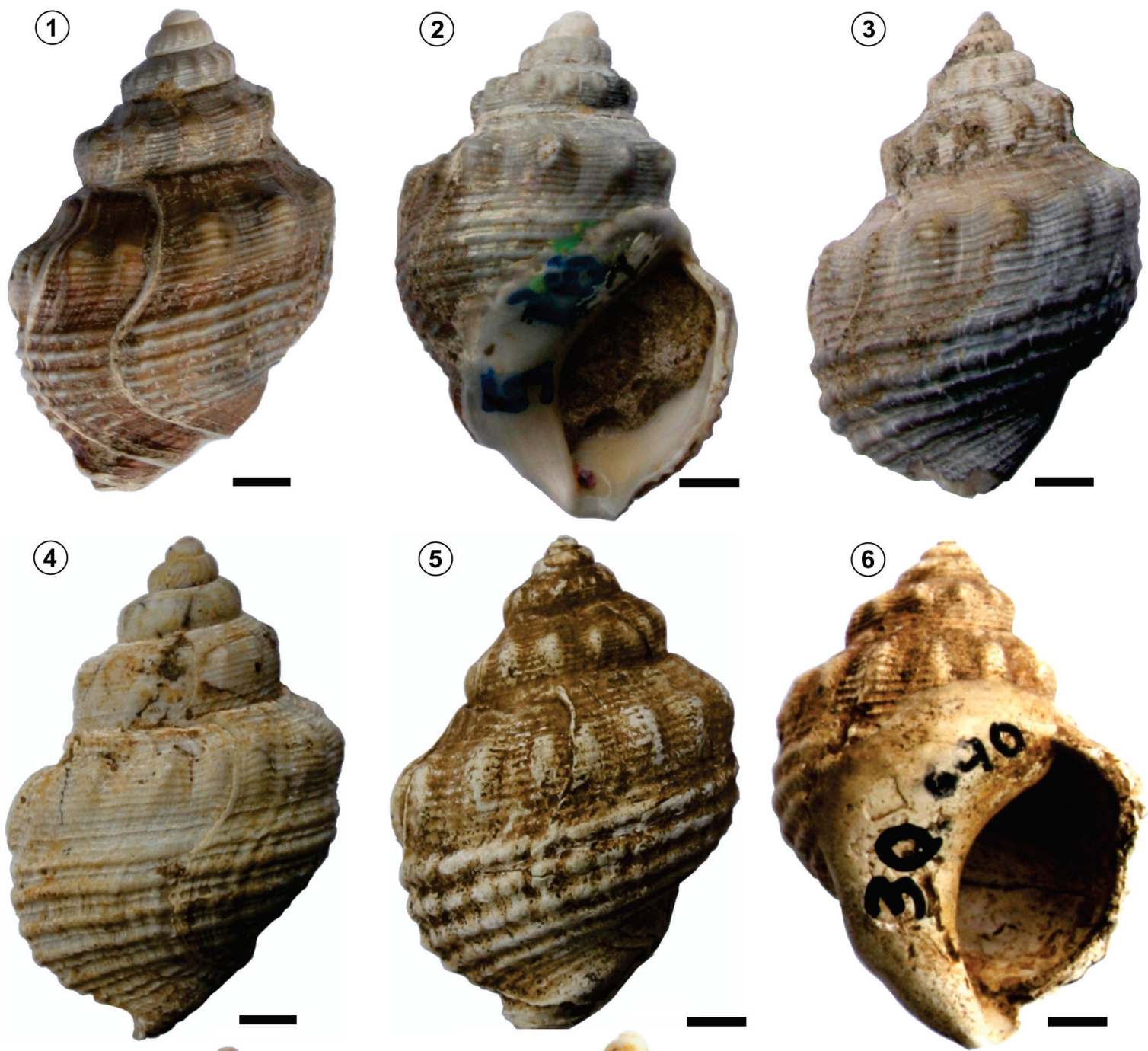

(7)
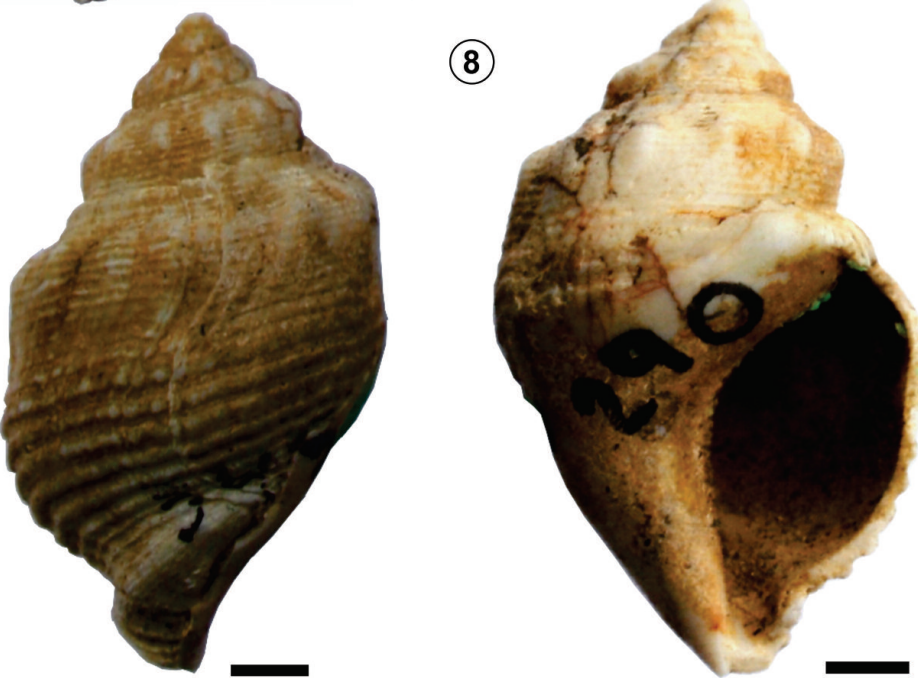

(9)

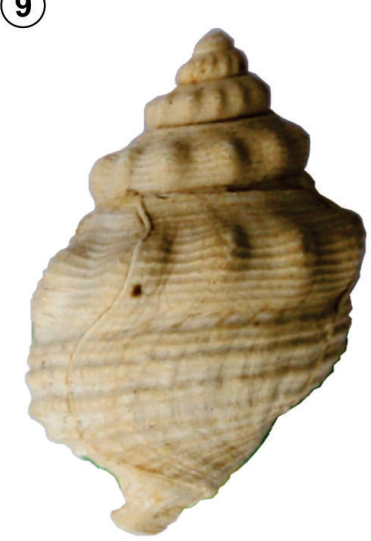

Figure 4. Morphological variability in P. ameghinoi from the early Miocene of Tierra del Fuego. 1-2, Morphological variant 1, CADIC PI 612-5. 3, CADIC PI 612-7. Both specimens from Carmen Silva Formation, Punta Basilica beds, Point PB 731. Note marked differences in the spiral cord strength in specimens from the same bed illustrated in 1 and 3. 4, Morphological variant 2, CADIC PI 611-17 Carmen Silva Formation, Carmen Silva beds, Point 545. 5-6, Morphological variant 3, CADIC PI 610-30, Carmen Silva Formation, Carmen Silva beds, Point 690. 7-8, Morphological variant 4, CADIC PI 611-290, Carmen Silva Formation, Carmen Silva beds, Point 545. 9, Morphological variant 5, CADIC PI 611-32, Carmen Silva Formation, Carmen Silva beds, Point 545. Scale bars $=5 \mathrm{~mm}$. 
considered a species very close to P. mirabilis (Powell, 1951; Morton, 1956), a subspecies of P. mirabilis (Strebel, 1908) or even a synonym of it (Troncoso et al., 2001).

In the southern ocean, species of Perissodonta are very common in the Eocene of Antarctica; after an apparent gap in the Oligocene they are widespread again in the Miocene of Patagonia and Tierra del Fuego. After the Miocene, the genus is not recorded in Patagonia and Tierra del Fuego and the extant $P$. mirabilis and $P$. georgiana are the only representatives of the family in the southern ocean.

\section{Perissodonta ameghinoi (Ihering, 1897)}

Figures 3-5

1897 Struthiolaria ameghinoi Ihering. Ihering, 1897, p. 289, fig. 14; Ortmann, 1902, p. 201, pl. 33, fig. 11a.

1908 Struthiolarella ameghinoi (Ihering). Steinmann \& Wilckens, p. 53, pl. 6, fig. 7.

1978 Struthiolarella densestriata (Ihering, 1897). Malumián et al., p. 282, pl. 2, fig. 2a-b.

1989 Struthiolarella fueguina (Ihering, 1907). Camacho \& Zinsmeister, p, 105, pl. 3, fig. 1.

2005 Perissodonta ameghinoi (Ihering, 1897). Nielsen, p. 1126, fig. 4.1-4.3.

Type material. According to Parodiz (1966) there are 12 syntypes under the number 763 in the Ihering collection housed in the MACN-Pi. Monte León Formation, early Miocene. Originally referred to the localities of La Cueva and Río Santa Cruz Mouth (Ihering, 1897), but according to Parodiz (1996) the locality better corresponds to Yegua Quemada, a few miles south of the mouth of the Río Santa Cruz, Santa Cruz Province, Argentina, early Miocene.

Referred Material. Eighty five well-preserved specimens used for measurements, listed in Table 1. From the early Miocene Carmen Silva Formation, Tierra del Fuego: Carmen Silva beds, point 690, 13 specimens (CADIC PI 610); point 545, 52 specimens (CADIC PI 611); point 135, seven specimens (CADIC PI 615); Punta Basílica beds, point PB 731, three specimens (CADIC PI 612); Viamonte Formation, point 164, CADIC PI 616; and Irigoyen Formation, point 841, two specimens (CADIC PI 613). From the early Miocene, Monte León Formation, Mount Entrance, Santa Cruz, six specimens (CADIC PI 617). Several partially preserved specimens from: the Carmen Silva Formation, point 690 CADIC PI 619; point 545 CADIC PI 620; and point PB 731 CADIC PI 621; the Viamonte Formation, CADIC PI 622; and the Irigoyen Formation, point 841; point 845 CADIC PI 623.

Description. Shell globose to sub-globose, whorls convex to squarish in outline, medium to large size (up to $52 \mathrm{~mm}$ in height), height greater than width. Protoconch abraded. Spire shorter than the last whorl (10.1 to $49.5 \%$, usually c. $32-41 \%$ of total height). Shell with up to six slightly rounded or squared whorls, with broad, concave sutural ramps and impressed suture. Last whorl with a sub-oval aperture, widening adapically. Columella strongly concave and smooth, with a twisted and narrow fasciole. Inner lip with wide and thick callus, siphonal canal short. Spiral sculpture of four to seven primary basal rounded cords of variable thickness, usually intercalated with second order cords. Surface between adapical cord and suture covered with nine to 13 threads, axial sculpture of 12 to 18 prominent, rounded to pointed, prosocline tubercles that abruptly appear on periphery of sutural ramp.

Remarks. When erecting Struthtiolaria ameghinoi Ihering (1897) stressed the point of the large size, scalariform outline, elongated nodules, and well-developed spiral cords and threads in this species. These characters were also considered distinctive of $P$. ameghinoi by subsequent authors, including Ortmann (1902), Ihering (1907), Steinmann \& Wilckens (1908) and Camacho \& Zinsmeister (1989), among others. They are also present in some specimens of Tierra del Fuego. For example, the scalariform (squarish) whorl outline generally mentioned for the Monte León specimens of $P$. ameghinoi (e.g., Fig. 5.6) is recorded in morphological variants 1, 2 and 5 (Fig. 4.1-2, 4.4, 4.9). Conversely, the more convex whorl outline commonly recorded in the Fuegian specimens, e.g., morphological variants 3, 4, 6, 7, and 8 (Fig. 4-5) is also recorded in some of the specimens of $P$. ameghinoi from the Monte Leon Formation (Fig. 5.5). In general, when a large number of specimens are considered in the analysis an intergradation of morphological and sculptural characters, such as relative height of the spire or width of the shell and number of cords, threads and tubercles, is clearly seen in $P$. ameghinoi from Tierra del Fuego and Santa Cruz (Fig. 3.1-3). For these reasons, both "Struthiolaria" fueguina (see also Camacho \& Zinsmeister, 1989) and "Struthiolarella" densestriata, non Ihering, 1897, described by Malumián et al. (1978) for the Carmen Silva Formation are considered in the 


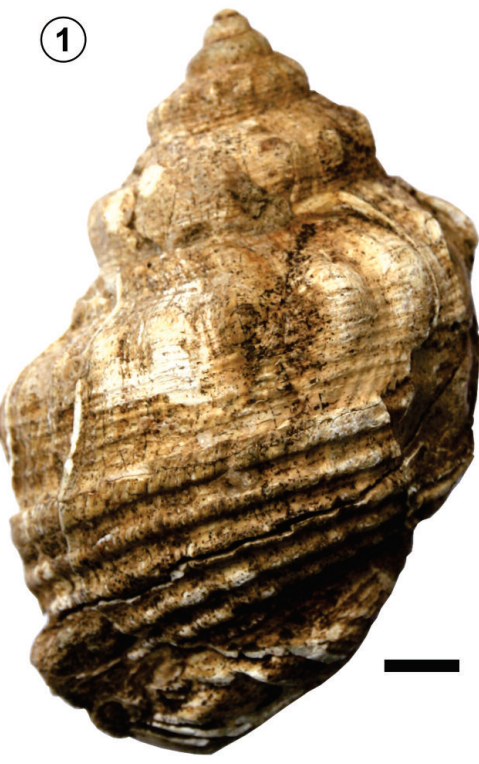

(4)
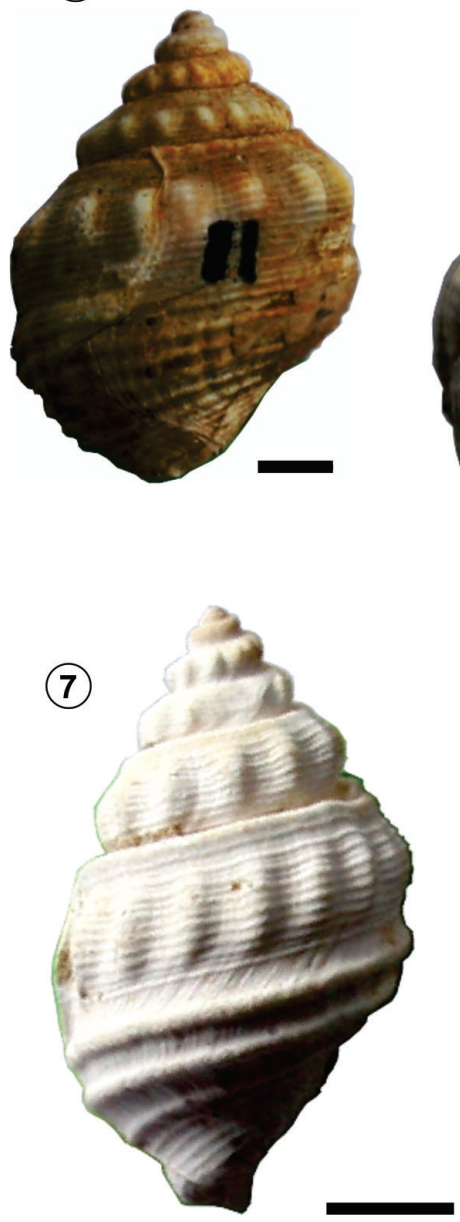

(2)
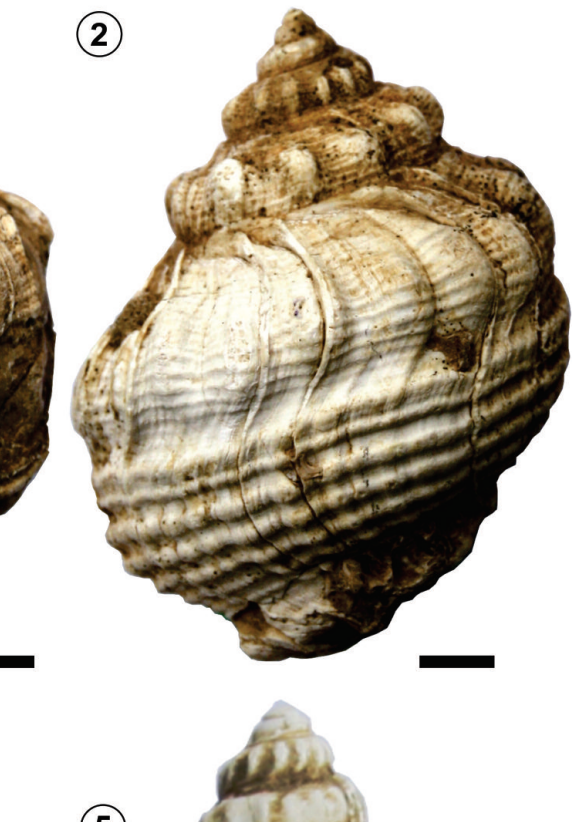

(5)
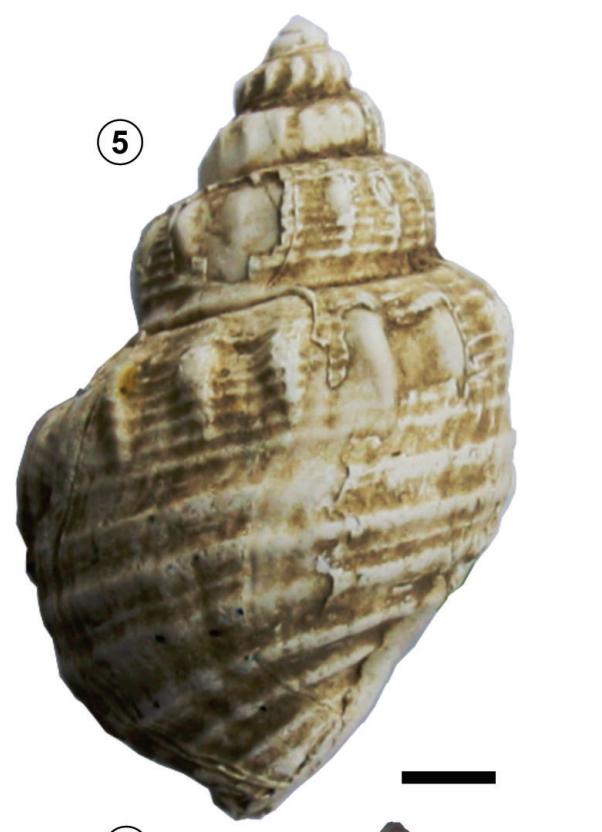

(8)

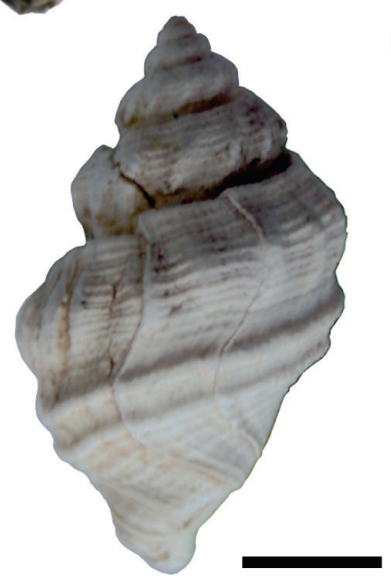

(3)

(6)

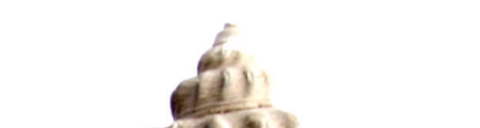

(9)

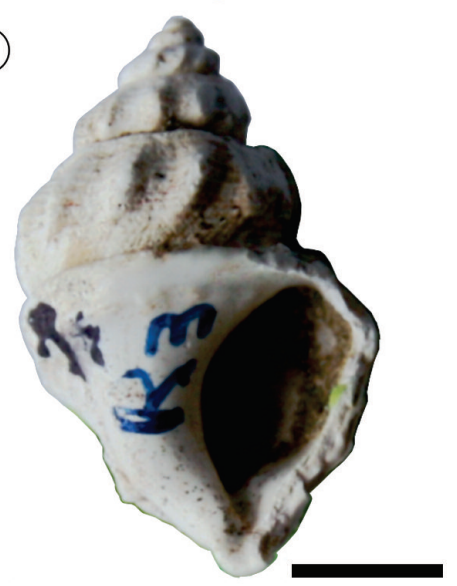

Figure 5. Morphological variability in P. ameghinoi from the early Miocene of Tierra del Fuego and Santa Cruz. 1, Morphological variant 6, CADIC PI 610-3, Carmen Silva Formation, Carmen Silva beds, Point 690. 2-3, Morphological variant 7, CADIC PI 611-22, Carmen Silva Formation, Carmen Silva beds, Point 545. 4, Morphological variant 8, CADIC PI 611-11, Carmen Silva Formation, Carmen Silva beds, Point 545. 5-6, $P$. ameghinoi from Mont Entrance, Santa Cruz, E, wide Morphological variant, CADIC PI 617-E21-3; 6, narrow Morphological variant, CADIC PI 617-E21-1. 7-9, P. ornata from Piedrabuena, Santa Cruz, G, CADIC PI 618-1; 8-9, CADIC PI 618-2. Scale bars= 5 mm. 

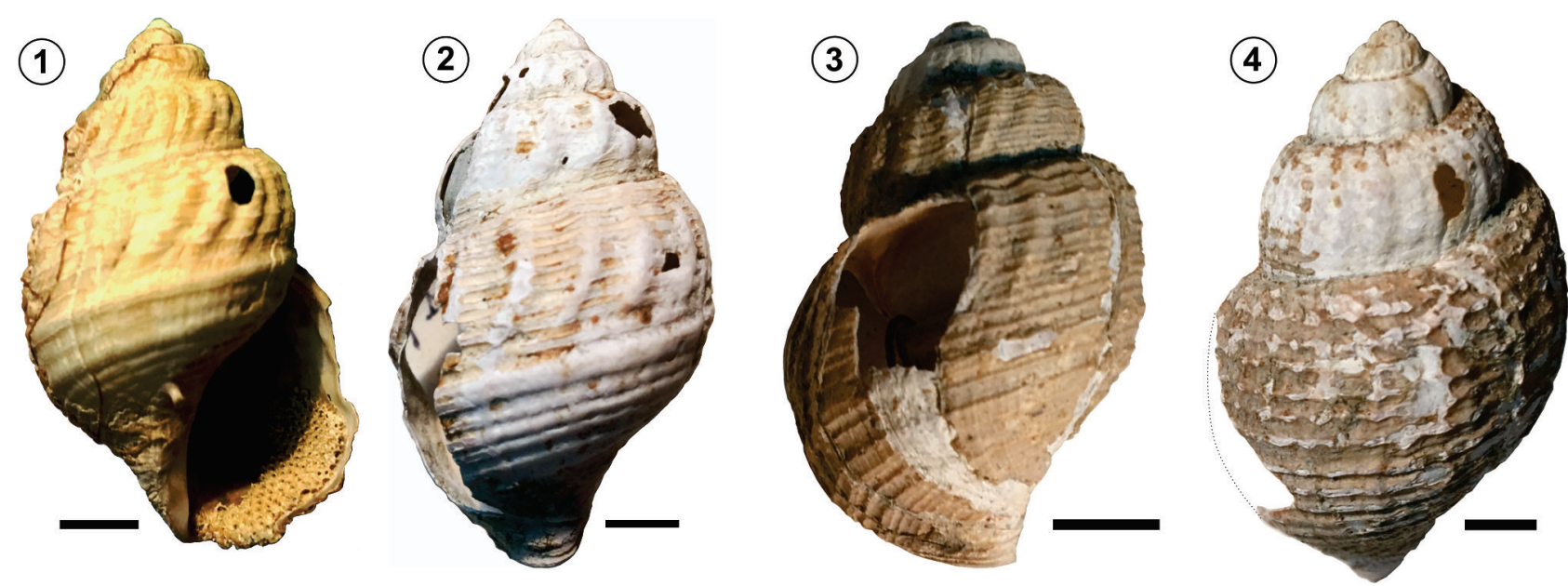

Figure 6. Morphological and ornamental variability in Perissodonta georgiana from Islas Georgias del Sur. 1-2, morphological variants with welldifferentiated strong spiral cords in the last whorl. Note the variability in the number of tubercles between 1 (high) and 2 (low); 1 , MACN-In 36298, Col. Eduardo L. Holmberg; 2, MACN-In 18955. 3, Morphological variant with slight differences in density and strength between spiral cords and threads, MACN-In 18953. 4, Morphological variant with spiral cords of uniform strength, MACN-In 18955 2, 3, 4, Col. Carcelles-Romero. Scale bars $=5 \mathrm{~mm}$

synonymy list of $P$. ameghinoi in the present study.

The struthiolariid gastropods collected in the San Julián Formation at Playa la Mina and Cabo Curioso (Fig. 1) are referred to Perissodonta sp., which differs from P. ameghinoi in bearing cords and threads of similar strength and a higher number of tubercles, about 18 per whorl.

Geographic and stratigraphic distribution. In Tierra del Fuego P. ameghinoi is distributed in the early Miocene Carmen Silva, Viamonte, and Irigoyen formations. Perissodonta sp. was also mentioned from the Conglomerado Cerro Águila (Feldmann et al., 2011), which is presently included in the Viamonte Formation (cf. Malumián \& Olivero, 2006).

Reference to the early Miocene to these formations is not well-constrained but it is supported by calcareous nannoplankton (Bedoya-Agudelo, 2019), foraminifera (Codignotto \& Malumián, 1981), molluscan content (del Río, 2021), and petrographic and isotopic data (Torres Carbonell \& Olivero, 2019; Olivero \& Torres Carbonell, 2021).

\section{DISCUSSION}

Previous studies of the Fuegian gastropod genus Perissodonta (ex-Struthiolaria or Struthiolarella) from the Carmen Silva Formation have recognized three species, including $P$. ameghinoi, $P$. densestriata, and $P$. fueguina (Steinmann \& Wilckens, 1908; Malumián et al., 1978;
Camacho \& Zinsmeister, 1989), but they were based on scarce material. The present systematic study of more than 100 specimens of the gastropod genus Perissodonta from different early Miocene stratigraphic units in Tierra del Fuego suggests, on the contrary, that they can be accommodated in a single, plastic species. Specimens of Perissodonta in our collection are characterized by highly variable morphological characters, particularly regarding the shell shape and the number and strength of spiral cords, spiral threads, and tubercles. The measurements of different shell shape attributes and counts of ornamental characters demonstrate this continuous variability (Fig. 3). In the plot of the relative height of the spire versus the shell relative width both the material from Tierra del Fuego and topotype specimens of P. ameghinoi from Mount Entrance, Santa Cruz cover the same morphospace (Fig. 3.1), forming a continuous trend, with no distinct cluster of points. Similarly, the plot of the shell height and width shows a continuous trend and intergradation among shell-shape parameters (Fig. 3.2). Accordingly, following the original suggestion of Steinmann \& Wilckens (1908) we have included in P. ameghinoi all the Tierra del Fuego material previously assigned to $P$. densestriata and P. fueguina (Malumián et al., 1978; Camacho \& Zinsmeister, 1989).

Nonetheless, there are some slight differences in the shell shape of some specimens, which may be attributed to 
geographic variations. According to the interpretation of $P$. ameghinoi given by Ihering (1897) and Ortmann (1902) the scalariform (squarish) whorl outline (e.g., Fig. 5.6) seems to be more common in the area of provenance of the type material in Santa Cruz. However, specimens with both convex and scalariform outlines coexist in the same bed in the Santa Cruz and Fuegian material but seemingly with different frequencies, being the convex whorl morphs more common in Tierra del Fuego and vice versa, supporting the idea of geographic variants of a single species.

Among the species of Perissodonta described from the early Miocene of Santa Cruz and Tierra del Fuego the oldest available names are $P$. ornata and $P$. ameghinoi (cf. Ihering, 1897; Steinmann \& Wilckens, 1908; Griffin \& Nielsen, 2008). P. ornata is clearly a very distinctive species (Fig. 5.7-9), which according to its canaliculated suture and the two or three strong cords in the last whorl can be readily distinguished from P. ameghinoi (cf. Marwick, 1924). This distinction is evident since both the shell shape parameters and number of ornamental characters form distinctive clusters, occupying a different morphospace than in $P$. ameghinoi (Fig. 3.2).

The interpretation of the rest of the Perissodonta species from other Eocene (Río Turbio Formation; Loreto Formation; La Meseta Formation), Oligocene (San Julián Formation), and early Miocene (Centinela-25 de Mayo and Chacay formations) deposits from Antarctica, Santa Cruz and Chile (see Zinsmeister \& Camacho, 1980; Camacho \& Zinsmeister, 1989; del Río, 2002), is beyond the scope of this study. Nonetheless, direct comparison with available material from these formations, indicates that the Eocene material is quite different from the Miocene P. ameghinoi. Perissodonta hatcheri from the Eocene Loreto Formation, Punta Arenas, Chile, and $P$. variabilis (Wilckens, 1911) and P. shackletoni (Zinsmeister \& Camacho, 1980), from the Eocene La Meseta Formation, Seymour Island, Antarctica (cf. Zinsmeister \& Camacho, 1980; Camacho \& Zinsmeister, 1989), have spiral cords of equal size and strength all over the shell, differing from the rest of the species of Perissodonta.

The latest Oligocene-earliest Miocene Perissodonta sp. from the San Julián Formation is characterized by the slight difference in strength of spiral cords and threads, and by the high number of tubercles, and thus it differs from the early
Miocene P. ameghinoi. Moreover, Perissodonta sp. was the only struthiolariid observed by the present authors in the San Julián Formation. We were unable to reproduce the finding of the material figured by Camacho \& Zinsmeister (1989) and described under P. ornata. Incidentally, this material (Camacho \& Zinsmeister, 1989: pl. II, fig. 3), however, lacks the characteristic canaliculated suture of $P$. ornata and bear six strong cords in the last whorl; hence it is quite different from Sowerby's species (see also Griffin \& Nielsen, 2008).

\section{CONCLUSIONS}

In the study of the fossil material of the struthiolariid gastropod Perissodonta from Tierra del Fuego we have reached the following conclusions.

1) Perissodonta is abundantly distributed in several early Miocene formations in Tierra del Fuego, including the Carmen Silva, Viamonte, and Irigoyen formations.

2) The number, strength, and density of spiral cords, spiral threads, and tubercles are highly variable in the studied material. Furthermore, the plot of morphological and ornamental parameters covers a continuous morphospace in the Fuegian material, thus it is not possible to use these characters for species differentiation.

3) The range of variability in the morphological and ornamental parameters in the Fuegian material is similar to that of Perissodonta ameghinoi from its type locality in early Miocene, Monte León Formation, Santa Cruz Province and, following the original suggestion of Steinmann \& Wilckens (1908), we assigned the Fuegian material to the same species.

4) The plot of similar morphological and ornamental parameters in Perissodonta ornata, also from the Monte León Formation, shows a distinct cluster, covering a different morphospace that clearly distinguishes this species from P. ameghinoi.

\section{ACKNOWLEDGMENTS}

We thank P. J. Torres Carbonell, E. Bedoya-Agudelo, and M. E. Raffi (CADIC-CONICET) for their help in part of the field work and we also thank the local support provided by P. Coria and G. Morales at San Sebastián, A. Goodall and T. Ayerza at the Estancia Viamonte, and P. J. López at Estancia María Luisa. We specially thank C. del Río and A. Tablado, MACN, for their help with the localization of fossil and extant material deposited at the Museo Argentino de Ciencias 
Naturales "B. Rivadavia". Positive comments and suggestions made by the Editors and the reviewers, anonymous and C. del Río, helped to improve the study. Part of this study was supported by PID UNTDF-A1 2016-2019 and by PUE-CADIC-CONICET 2016.

\section{REFERENCES}

Bedoya-Agudelo, E. L. (2019). Asociaciones de nanofósiles calcáreos del Paleoceno-Mioceno de Tierra del Fuego. Bioestratigrafía, Paleoecología y Paleooceanografía [Tesis Doctoral, Facultad de Ciencias Exactas y Naturales, Universidad de Buenos Aires]. Retreived from http://digital.bl.fcen.uba.ar/Download/Tesis.

Beu, A. G. (2009). Before the ice: biogeography of Antarctic Paleogene molluscan faunas. Palaeogeography, Palaeoclimatology, Palaeoecology, 284, 191-226.

Biddle, K. T., Uliana, M. A., Mitchum Jr., R. M., Fitzgerald, M. G., \& Wright, R. C. (1986). The stratigraphy and structural evolution of the central and eastern Magallanes basin, southern South America. In P. A. Allen, \& P. Homewood (Eds.), Foreland Basins (pp. 41-66). International Association of Sedimentologists, Special Publication 8.

Camacho, H. H. \& Zinsmeister, W. J. (1989). La Familia Struthiolariidae Fisher, 1884 (Molusca, Gastropoda) y sus representantes en el Terciario Patagónico. Simposio Invertebrados Fósiles Del Cenozoico y $4^{\circ}$ Congreso Argentino de Paleontología y Bioestratigrafía (pp. 99-110). Mendoza.

Codignotto, J. O. \& Malumián, N. (1981). Geología de la región al Norte del Paralelo $54^{\circ} \mathrm{S}$ de la Isla Grande de Tierra del Fuego. Revista de la Asociación Geológica Argentina, 36, 44-88.

Dalziel, I. W. D. (1981). Back-arc extension in the southern Andes: a review and critical reappraisal. Philosophical Transactions of the Royal Society of London, Series A-Mathematical, Physical, and Engineering Sciences, 300(1454), 319-335.

Darwin, C. (1846). Geological observations on South America. Being the third part of the geology of the voyage of the Beagle, under the command of Capt. Fitzroy, R.N. during the years 1832 to 1836. Smith, Elder \& Co., London.

del Río, C. J. (2002). Moluscos del Terciario marino. Geología y Recursos Naturales de Santa Cruz. En M. J. Haller (Ed.), Geología y Recursos Naturales de Santa Cruz, Relatorio $15^{\circ}$ Congreso Geológico Argentino. Asociación Geológica Argentina.

del Río, C. J. (2004). Tertiary marine molluscan assemblages of eastern Patagonia (Argentina): a biostratigraphic analysis. Journal of Paleontology, 78(6), 1097-1122.

del Río, C. J. (2021). Paleoclimate and changing composition of the Paleogene-Neogene shallow Molluscan Assemblages of Patagonia. Journal of South American Earth Sciences, 108. doi.org/10.1016/j.jsames.2021.103209

Feldmann, R. M., Schweitzer, C. E., Casadío S., \& Griffin, M. (2011). New Miocene decapoda (Thalassinidea, Brachyura) from Tierra del Fuego, Argentina: Paleobiogeographic implications. Annals of Carnegie Museum, 79, 91-123.

Galeazzi, J. S. (1998). Structural and stratigraphic evolution of the western Malvinas Basin, Argentina. Bulletin of the American Association of Petroleum Geologists, 82, 596-636.

Genta Iturrería, S. \& Griffin, M. (2018). A rewiew of the South American members of the family Struthiolariidae Fischer. Publicación Electrónica de la Asociación Paleontológica Argentina 19(1), R52.

Griffin, M. \& Nielsen, S. N. (2008). A revision of the type specimens of Tertiary molluscs from Chile and Argentina by d'Orbigny (1842), Sowerby (1846) and Hupé (1854). Journal of Systematic
Palaeontology, 6, 251-316.

Ihering, H. von. 1897. Os molluscos dos terrenos terciarios da Patagonia. Revista do Museu Paulista, 2, 217-382.

Ihering, H. von. 1907. Les Mollusques fossiles du Tertiaire et du Crétacé superieur de l'Argentina. Anales del Museo Nacional de Buenos Aires, Serie 3, Tomo 7, 1-608.

Lamarck, J. B. (1816). Liste des objets représentés dans les planches de cette livraison. In Tableau encyclopédique et méthodique des trois règnes de la Nature. Mollusques et Polypes divers (pp. 116). Agasse, Paris.

López Cabrera, M. I. \& Olivero, E. B. (2018). Morphological variability in the gastropod Perissodonta Martens (Struthiolarella) from the Early Miocene of Tierra del Fuego. Publicación Electrónica de la Asociación Paleontológica Argentina 19(1), R74.

Malumián, N., Camacho, H. H., \& Gorroño, R. (1978). Moluscos del Terciario inferior ("Magallanense") de la Isla Grande de Tierra del Fuego (República Argentina). Ameghiniana, 15(3-4), 265-284.

Malumián, N. \& Olivero, E. B. (2005). El Oligoceno-Plioceno marino del río Irigoyen, costa atlántica de Tierra del Fuego, Argentina: Una conexión atlántico-pacífica. Revista Geológica de Chile, 32, 117-129.

Malumián, N. \& Olivero, E. B. (2006). El Grupo Cabo Domingo, Tierra del Fuego: bioestratigrafía, paleoambientes y acontecimientos del Eoceno-Mioceno marino. Revista de la Asociación Geológica Argentina, 61, 139-160.

Martens, E. von. (1878). Einige Conchylien aus den kälteren Meeresgegenden der südlichen Erdhälfte. Sitzungsbericht der Gesellschaft naturforschender Freunde zu Berlin, 20-26.

Marwick, J. (1924). The Struthiolariidae. Transactions of the New Zealand Institute, 55, 161-190.

Morton, J. E. (1956). The evolution of Perissodonta and Tylospira (Struthiolariidae). Transaction of the Royal Society of New Zealand, 83(Part 3), 515-524.

Nielsen, S. N. (2005). Cenozoic Strombidae, Aporrhaidae, and Struthiolariidae (Gastropoda, Stromboidea) from Chile: their significance to the interpretation of southeast Pacific biogeography and climate. Journal of Paleontology, 79, 11201130.

Olivero, E. B. \& López Cabrera, M. I. (2020). A new shallow-marine, high-latitude record of the trace fossil Macaronichnus in Miocene, reworked delta-front clinoform, Punta Basílica, Tierra del Fuego, Argentina. Ichnos. https://doi/10.1080/10420940. 2020.1755854

Olivero, E. B., López Cabrera, M. I., \& Reguero, M. (2015). Icnología de los depósitos fluviales de la Formación Cullen (Mioceno, Tierra del Fuego) y su relación con la Formación Santa Cruz, (Mioceno) de Patagonia. $3^{\circ}$ Simposio Latinoamericano de Icnología (pp. 60). Colonia del Sacramento, Uruguay.

Olivero, E. B. \& Malumián, N. (2008). Mesozoic-Cenozoic stratigraphy of the Fuegian Andes, Argentina. Geologica Acta, 6, 5-18.

Olivero, E. B., Malumián, N., \& Palamarczuk, S. (2003). Estratigrafía del Cretácico Superior-Paleoceno del área de Bahía Thetis, Andes fueguinos, Argentina: acontecimientos tectónicos y paleobiológicos. Revista Geológica de Chile, 30, 245-263.

Olivero, E. B., Malumián, N., Palamarczuk, S., \& Scasso, R. A. (2002). El Cretácico Superior-Paleógeno del área del Río Bueno, costa atlántica de la Isla Grande de Tierra del Fuego. Revista de la Asociación Geológica Argentina, 57, 199-218.

Olivero, E. B. \& Torres Carbonell, P. J. (2021). Stratigraphy and depositional architecture of the Viamonte Formation, Miocene, Tierra del Fuego, Argentina: the interplay between deep-marine 
transverse and longitudinal depositional systems. Revista de la Asociación Geológica Argentina, 78(2), 135-162. https://revista. geologica.org.ar/raga/article/view/244

Ortmann, A. E. (1902). Tertiary invertebrates. Volume 4, Palaeontology 1, Part 2. In W. B. Scott (Ed.), Reports of the Princeton University Expedition to Patagonia, 1896-1899 (pp. 45-332). Pierpoint Morgan Publishing Foundation, Princeton.

Parodiz, J. J. (1996). The taxa of fossil Mollusca introduced by Hermann von Ihering. Annals of Carnegie Museum, 65, 183-296.

Parras, A. \& Griffin, M. (2009). Darwin's great Patagonian tertiary formation at the mouth of the río Santa Cruz: a Reappraisal. Revista de la Asociación Geológica Argentina, 64(1), 70-82.

Philippi, R. A. (1887). Los fósiles terciarios i cuartarios de Chile. F.A. Brockhaus, Leipzig, and Museo Nacional de Historia Natural, Santiago.

Powell, A. W. B. (1951). Antarctic and subantarctic Mollusca: Pelecypoda and Gastropoda, collected by the ships of the Discovery Committee during the years 1926-1937. Discovery Reports, 26, 47-196.

Smith, E. A. (1875). Description of some new shells from Kerguelen's Island. Annals and Magazine of Natural History, 16, 67-73.

Steinmann, G. \& Wilckens, O. (1908). Kreide-und Tertiärfossilien aus den Magellansländern gesammelt von der schwedischen Expedition 1895-1897. Arkiv för Zoologi, 4(6), 1-119.

Strebel, H. (1908). Die Gastropoden. In Wissenschaftliche Ergebnisse der Schwedischen Südpolar-Expedition 1901-1903 unter Leitung von Dr. Otto Nordenskjöld (pp. 1-111). Stockholm.

Torres Carbonell, P. J., Cao, S. J., González Guillot, M., Mosqueira González, V. M., Dimieri, L. V., Duval, F., \& Scaillet, S. (2020). The Fuegian thrust-fold belt: From arc-continent collision to thrustrelated deformation in the southernmost Andes. Journal of South American Earth Sciences, 102, 102678. doi.org/10.1016/ j.jsames.2020.102678

Torres Carbonell, P. J., Dimieri, L., \& Olivero, E. B. (2011). Progressive deformation of a Coulomb thrust-wedge: the eastern Fuegian Andes thrust-fold belt. In J. Poblet \& R. Lisle (Eds.), Kinematic evolution and structural styles of fold and thrust belts (pp. 123-147), Geological Society, London, Special Publication, London.
Torres Carbonell, P. J. \& Olivero, E. B. (2012). Sand dispersal in the southeastern Austral Basin, Tierra del Fuego, Argentina: outcrop insights from Eocene channeled turbidite systems. Journal of South American Earth Sciences, 33, 80-101. doi.org/10.1016/ j.jsames.2011.08.002

Torres Carbonell, P. J. \& Olivero, E. B. 2019. Tectonic control on the evolution of depositional systems in a fossil, marine foreland basin: Example from the SE Austral Basin, Tierra del Fuego, Argentina. Marine and Petroleum Geology, 104, 40-60.

Torres Carbonell, P. J., Olivero, E. B., \& Dimieri, L.V. (2008). Control en la magnitud de desplazamiento de rumbo del Sistema Transformante Fagnano, Tierra del Fuego. Argentina. Revista Geológica de Chile, 35, 63-79.

Troncoso, N., Goethem von, J. L., \& Troncoso, J. S. (2001). Contribution to the marine molluscan fauna of Kerguelen Islands, South Indian Ocean. Iberus, 19(1), 83-114.

Zinsmeister, W. J. \& Camacho, H. H. (1980). Late Eocene Struthiolariidae (Mollusca, Gastropoda) from Seymour Island, Antarctic Peninsula, and their significance to the biogeography of early Tertiary shallow-water faunas of the southern hemisphere. Journal of Paleontology, 54, 1-14.

Editorial Note: Both this work and the nomenclatural acts it contains have been registered in the ZooBank. The work is permanently archived in the Internet Archive.

LSID urn:Isid:zoobank.org:pub:A04492A0-5E4E-4636-A18C-9CDFD32E3DA6

doi: 10.5710/PEAPA.24.07.2021.388

Recibido: 1 de marzo 2021

Aceptado: 24 de julio 2021

Publicado: 22 de septiembre 2021
Acceso Abierto Open Access

This work is licensed under

CC BY-NC 4.0
(1)(1) 